\title{
DEL SENTIDO DE LA MUERTE EN PAUL RICOEUR
}

\author{
Belén Castellanos Rodríguez \\ IES Virgen de Covadonga (Asturias) - UNED - EMUI
}

http://dx.doi.org/10.5209/rev_NOMA.2015.v45.n1.51331

\begin{abstract}
Resumen.- Partiendo de la obra de Paul Ricoeur, el siguiente artículo presenta una reformulación no humanista de la pregunta por el sentido de la vida, con la que se trata de salir del nihilismo pero también de la idea de que el ser humano puede, felizmente, renunciar a tal interrogante y congratularse sin más, con la afirmación del caos o con la fabricación de sentidos meramente subjetivos o gregarios, provisionales o superficiales. Se muestra la necesidad de rescatar el papel de la fe, del destino y del amor sacrificial, desplazando la pregunta por el sentido de la vida a la pregunta por el sentido de la muerte que, si se logra contestataria y significante, se colocará como respuesta y acabamiento del actuar hermenéutico.
\end{abstract}

Palabras clave.- Ricoeur, fe, sentido de la vida, muerte, amor, religión, Dios, hermenéutica.

\begin{abstract}
Based on the work of Paul Ricoeur, the following article presents a non- humanist reformulation of the question of the meaning of life, with which to come out of nihilism and the idea that humans can, happily, drop out this question and welcome without more, to the affirmation of chaos or manufacture of merely subjective or gregarious or provisional senses. The need to rescue the role of faith, fate and sacrificial love is show, shifting the question of the meaning of life the question to the meaning of death which, if achieved rebellious and significant, will be placed in response and finishing hermeneutic act.
\end{abstract}

Keyword.- Ricoeur, meaning of life, death, sacrificial love, religion, God, hermeneutics.

A Marcos Ríos,

\section{Introducción.}

¿Qué está ocurriendo cuando una pierde el temple para vivir? Creo poder adelantar una respuesta provisional. Si nos paramos e intentamos cifrar, fenoménicamente, qué está ocurriendo en el ocaso del brío vital, fácilmente nos daremos cuenta de que la reflexión le ha ganado la carrera al cuerpo y, en ese momento, la empecinada búsqueda de sentido da lugar a una honda sensación de sin-sentido, o, expresado en términos intrasubjetivos, a una obscura sucesión de ¿para qué?

Siendo que el cuerpo debería saltar de la cama con la luz de la mañana, deseoso de un nuevo día, y la mente la que se pusiera a trabajar después, para dar sendero al impulso, las cosas, torcidas, comienzan a sucederse al contrario y es la mente la que obscura como es, cuando se ha adueñado de las pulsaciones de la existencia, despierta antes, impidiendo que el cuerpo se desperece 0 , agotándolo prematuramente con reflexiones y demandas de razón, intentando encontrar argumentos que justifiquen por qué debería levantarme mejor que quedarse indefinidamente bajo las mantas, termina por apercibirse de que, con razones o sin ellas, ese cuerpo ya no le responde ni 
puede procurar infraestructura a ningún plan.

Así, podríamos concluir, engalanados por el pesimismo optimista del postnihilismo o por cualquier constructivismo de estos tiempos postmodernos, que debemos acabar con la rumia, que viva la imaginación, que muerte a la búsqueda de sentidos predeterminados, etc. Sin embargo, si me pregunto por qué elegí la filosofía, solo obviando o expulsando las angustias de la infancia, podría envalentonarme y acudir a esos discursos tan actuales de la independencia, de la fuerza impostada del adulto y de ese vitalismo que encubre, para disimularlo, un "refinado" academicismo, para declarar que la elegí para jugar con las perspectivas, para inventar sentidos siempre nuevos, para volver alegremente al instante cero de cualquier emprendimiento, para remontar la inocencia del inconsciente "huérfano, ateo y anarquista" (que diría Gilles Deleuze)... Sería una impostura, pues mi niñez no fue la del niño que ríe y goza por solo levantar castillos de arena para luego derrumbarlos.

Pienso que sí es una niña la que eligió la filosofía, pero una niña que lloraba la muerte, que no se explicaba la crueldad del desvanecimiento de todas las cosas, que no podía tomar con levedad el triste desenlace letal de esas vidas, pequeñas vidas de pájaros, nacidas de un cúmulo incontable de circunstancias únicas en un instante de oportunidad, de tantos esfuerzos de supervivencia, de la superación de dolorosos momentos de fragilidad, de la constancia que aguanta golpes para aprender a volar; una niña, en definitiva, que lloraba la finitud. $Y$ de la aflicción por la finitud se va a la búsqueda de la verdad. Casi podría afirmar que la Verdad, así con mayúscula, es eso que una habría alcanzado cuando sabe qué decir en un funeral. Yo no lo sé. Filosofaremos mientras no sepamos qué decir ante el drama de la finitud, pero solo a condición de que la finitud no se haya apoderado de nosotros. La Verdad es un ir respondiendo de la muerte, es decir, de la finitud con un espíritu religioso al que su religión no le baste.

Lo mismo es preguntarse por qué moriré si deseo vivir que por qué nací, si la vida ya no parece ofrecer nada más que la espera por la muerte, si ya no sé por qué dilatar el momento, si ya nada sorprendente parece acechar tras la esquina, o si ninguna conquista me queda esperar o si las conquistas ya no tienen brillo ni emoción. Todo esto constituye una definición, bien sea muy imperfecta o poco rigurosa, de la pérdida de la fe. Me atrevería a afirmar ahora, y con ello lograr cierto hilo expositivo que me dé el derecho a pasar de una cosa a la otra, que perder la fe es perder la expectativa del amor.

La experiencia del amor irrumpe dando sentido y regocijo al hecho de haber nacido, incluso al haber nacido del más melancólico. Y el amor es tan extático que nos reconcilia con la muerte pues pareciera que de un trago ya tomáramos toda la eternidad en un instante. $\mathrm{Y}$, ¿cuándo dejamos de creer en esta redención? Dejamos de creer en esta redención en un punto muy concreto, 
terriblemente nombrable: cuando cae la ilusión de conexión ${ }^{1}$.

En una biografía inquieta, abierta al erotismo, cuántas veces hemos sentido, junto a alguien, una química tan fuerte que nos hace llorar de emoción y pensar que esa atmósfera que acaba de surgir, lo ha hecho, indudablemente, de entre los dos y que nos transporta al fondo de la tierra y a lo alto de los cielos a ambos. Estamos, en esos momentos, cargados de fe (bien le digan oxitocina los biólogos o los médicos). No es tanto el desamor, sino la desconexión o la pérdida de la ilusión de conexión, la sospecha fundada o infundada o la simple no-certeza de que el otro con-vive esa redención, la que da al traste con la fe, con la expectativa del amor. No hay nada peor que empezar a pensar que la mirada del otro solo es el reflejo de la nuestra, nada peor que este tipo de solipsismo, nada peor que la irrupción de la duda cartesiana en un universo platónico.

Y al punto que espero haber conseguido tramar una relación suficientemente coherente o sensualmente coherente entre la pregunta por la finitud, por la fe y por el amor, espero también haber generado el ambiente propicio para que el repaso de los escritos de Paul Ricoeur caiga en terreno propicio, es decir, venga a responder o a re-exponer mejor que yo, mejor que otros, la hondura o radicalidad de los vértigos exhibidos en esta personal introducción.

1 Téngase en cuenta que no uso el término fantasía para indicar el carácter falso, en este caso, de la sensación de conexión o de la conexión misma. Tampoco pretendo darle a dicha sensación un correlato de realidad indubitable. Es por ello que asimilo esta fantasía de conexión con la fe, no siendo la fe o la convicción, la creencia en fraudes o simulaciones ni tampoco la certeza devenida de demostraciones empíricas o racionales, es decir, fácticas o lógicas, sino ese impulso vital que se mantiene en la ascesis o aspiración a alguna verdad esencial que, como arcké o primer principio, tan solo puede ser intuido o presupuesto o, si queremos, demostrado por ese método que no es, realmente una demostración y conocemos como reducción al absurdo: aspiración hacia aquello sin lo cual todo carecería de sentido. Por esa precisa razón examinaremos la legitimidad de la pregunta por el sentido e incluso de la exigencia de sentido, haciendo una apuesta religiosa por ella.

Así, propongo recoger el significado genético del término fantasía y así entenderla, al modo griego, como aparición, manifestación, imagen o, en términos generales, aquello que puede ser percibido, sentido. Si se desea enlazar con el lenguaje psicoanalítico, recordaremos que Freud se resistía a decantarse en cuento al carácter de realidad o irrealidad objetiva del motivo o argumento de la fantasía, no considerando, además que dirimir tal cuestión fuera demasiado relevante, pues el acontecimiento psíquico, en todo caso, tiene su propia verdad, su propia substancia, estructurando incluso la línea de comportamientos exteriorizados. Más aún se puede hacer este uso si pensamos en las fantasías originarias, aquellas que, impersonales y sin relación necesaria con las vivencias del sujeto, conforman la base del inconsciente a través de la herencia filogénica de los símbolos, entendiéndose entonces que más allá de lo humano, se nos interpela con signos enigmáticos que recibimos a través del alma inconsciente.

Siguiendo la tradición griega y también la psicoanalítica tomaré indistintamente la palabra fantasía o la palabra fantasma pues, lo mismo, etimológicamente significa lo que aparece, lo que se muestra, lo que brilla. Gracias al psicoanálisis y a las precisiones lacanianas, podemos también interrogarnos acerca de la actualidad o inactualidad del fantasma. Como nuestra propia intuición indica, el fantasma es actual en tanto que se nos presenta, alegrándonos, atormentándonos, o generando cualquier otro afecto. En cambio, parece provenir del submundo, del pasado. Se dice fantasma, comúnmente, de la aparición de un difunto. Así, es actual e inactual: está o es pero insistiendo más que existiendo. En definitiva, la fantasía, el fantasma, es una virtualidad. 


\section{La fantasía de conexión como dimensión religiosa.}

La fantasía de conexión se me antoja como la presunción esencial, la que nos es necesaria para vivir más allá de la supervivencia, para poder esperar algo de la vida y para poder agradecer algo en el momento de la muerte. Solo la fantasía de conexión permite que el laberinto de la mente no se adelante a nuestro cuerpo, angostándolo, y que nuestro cuerpo no camine sin espíritu, al margen del deseo de verdad, ya robótico entonces. Porque creo que no se puede auténticamente vivir en la nada, en el caos tedioso, al que no le siguiera ningún reordenamiento, o porque sé, al menos, que yo, como muchos, no lo podemos hacer, vale la pena interpelar, una vez más, a nuestra dimensión religiosa y demandar al mundo, a nuestro mundo, las condiciones necesarias para no tener que renunciar a ella.

En otras ocasiones y a propósito de otros estudios y en compañía de otros personajes filosóficos, podría abrir y cerrar esta cuestión con un ontológico llamamiemto al Ser, a la pregunta por el Ser, por la eternidad. En cambio, me voy a arriesgar, contra la moda, a reclamar a Dios o cuanto menos, a reclamar nuestro derecho a proponer algún modo de su existencia. Sé que hablar del Ser y hablar de Dios podría tratarse de lo mismo si la religiosidad se reduce a filosofía racional o si la filosofía se instrumentara del todo al servicio de cualquier discurso teológico. Pero, como indica Ricoeur la palabra Dios añade algo que no se le presupone al Ser, que no se le pide o que incluso se le niega: el sentido: "La palabra Dios dice más que la palabra ser porque presupone todo el contexto de los relatos, las profecías, las leyes, los salmos, etc. Seguir la palabra Dios es seguir su flecha de sentido. Por flecha de sentido entiendo su poder capaz de reunir las significaciones parciales, inscriptas en los diversos discursos parciales, y abrir un horizonte que no se deja delimitar por la clausura de ningún discurso" (Ricoeur, 2008, pp. 62-63).

Consciente de que exigirle un sentido a la vida y, más aún, pretender descubrirlo, parece propio de aquel humanismo desfasado tan criticable ya y del cual yo misma he recontado y recuento mil veces sus consecuencias funestas (para el espíritu, para la historia humana, para la salud, etc.), deseo hacerme cargo de ese grave que es el sentido de la vida y pensarlo, desde otro lado que no sea el humanismo ni el nihilismo ni, tal vez, el postnihilismo, sino, simplemente, desde la necesidad. Se trata aquí y ahora de una pregunta religiosa y no humanista. Si es así es porque no estamos buscando el sentido en metas y logros ni en nada comprometido con la idea de progreso, que considero felizmente desechada por nuestra epocalidad, sino como antes manifestaba, en aquella palabra que pudiera, verdaderamente y sin mascaradas, dar consuelo al luto. Ricoeur nos dona aquí otra significación, la de Cristo, "capaz de incorporar todas las significaciones religiosas en un único símbolo, el símbolo del amor sacrificial más fuerte que la muerte" (Ricoeur, 2008, p. 63).

En el imaginario bíblico, entendiendo que reúne antiguos símbolos religiosos, se nos presenta la figura de Cristo como respuesta o modo de comprender la 
pregunta por la muerte, por la finitud y, así también por el nacimiento, las angustias, las pasiones, el espectáculo de la crueldad (nombres, al fin, de la finitud). Solo parece posible transcender la muerte por el amor, del mismo modo que el amor, como observaríamos en Georges Bataille, ofrece una experiencia de la muerte en tanto que amor y muerte implican continuidad ontológica, deshaciendo la concreción, la insuficiencia que experimentamos como entes separados, recortados, desconectados de todo lo demás. Si al nacer, nos separamos, indicaba Anaximandro, al morir volvemos a la reunión, nos reunimos, retornamos a la indeterminación de la que todas las cosas del universo brotan y a la que todas regresan ${ }^{2}$.

No olvido, sin embargo que en esta ocasión deseo trazar una propuesta religiosa más allá de una ontología desnuda. Por ello, quiero no solo hablar de Dios como palabra que añade algo al Ser sino también hablar del amor como palabra que añade algo a la reunión. El amor es esa disposición a dejarse interpretar y ese dejarse interpretar se hace interpretando, a su vez, al otro. Con nuestras observaciones del otro dejamos que ese otro conozca nuestras preguntas, nuestras incógnitas, nuestras curiosidades $y$, en definitiva, los problemas que nos constituyen. Es así como en nuestra labor interpretativa nos ofrecemos a la interpretación, tal y como en la interpretación de los textos sagrados, dejamos que ellos mismos nos digan, a su vez, quiénes somos. Hacer el amor es hacer hermenéutica.

\section{Fe, hermenéutica y amor.}

Antes mencionábamos el carácter estático de la experiencia amorosa en relación a esa fantasía de conexión que otorga, no tanto una despreocupación ante la muerte, sino una afirmación de la vida hasta la muerte como diría Bataille. Recién, explorábamos una nueva aproximación hacia el concepto de interpretación y de apertura hermenéutica, con el amor, la donación y la exposición como límites y condiciones suyas de posibilidad. Ambos caminos producen, entiendo, una resonancia religiosa que conduce a la fe.

En la fe se reunirían tanto el aliento vital, ese que habilita al espíritu del cuerpo para encontrarse esperanzado, emocionado, dispuesto para la vida y para el

2 En torno a esta temática se desarrolla mi artículo "El erotismo como fascinación ante la muerte en Georges Bataille" publicado en Nómadas. Revista Crítica de Ciencias Sociales y Jurídicas 26 (2010.2). Traigo aquí un fragmento en el que cito la correlación entre ambos pensadores: "La sexualidad y la muerte se pertenecen la una a la otra: <<La muerte de uno es correlativa al nacimiento de otro. La vida es siempre un producto de la descomposición de la vida. Antes que nada es tributaria de la muerte, que le hace un lugar; luego, lo es de la corrupción, que sigue a la muerte y que vuelve a poner en circulación las substancias necesarias para la incesante venida al mundo de nuevos seres >> (G. Bataille: El erotismo. Ed. Tusquets. Barcelona, 2007. p. 59). De este modo, Bataille inicia un análisis que parte de la reescritura de Anaximandro. Recordemos la famosa frase de éste recogida así por Simplicio: $<<E$ El nacimiento a los seres existentes les viene de aquello en lo que convierten al perecer, "según la necesidad, pues se pagan, los unos a los otros, mutua pena y retribución por su injusticia según la disposición del tiempo", como Anaximandro dice en términos un tanto poéticos>> (S. Kirk, J. E. Raven y M. Schofield: Los filósofos presocráticos. Ed. Gredos, Madrid, 1994. p. 177)". 
desafío ante una muerte que no llegaría a alcanzar nunca al éxtasis eterno del momento del amor; como la confianza radical a partir de la cual se puede vivir realmente en tanto que se arriesga la vida o, en el extremo, tal como condensa la imagen de Cristo, se sacrificaría por una todavía mayor, con la que se transciende la muerte y se conjura la finitud. Incluso resultaría extraño denominar ser finito a uno que entrega la vida por amor. Así, desde este trazado, hacer el amor es hacer hermenéutica y hacer hermenéutica es un acto posibilitado por la fe que, obviamente, escaparía al registro clausurado de toda hermenéutica.

Al fin, como decíamos, la fantasía de conexión constituye esa fe a partir de la cual permitimos que alguien nos dé un nombre en el justo momento en que leemos a ese alguien. Escuchemos a Ricoeur en torno a la fe: "puede designarse a la fe como <<inquietud última>>, subyacente a todas nuestras decisiones. Podemos asimismo llamarla <<sentimiento de dependencia absoluta >> para subrayar el hecho de que nunca es más que una respuesta a un querer que nos precede. Podemos incluso llamarla <<confianza incondicionada>>, si no deseamos separarla de la esperanza que abre un camino a pesar de todos los obstáculos y que convierte toda razón de desesperar en razón de esperar" (Ricoeur, 2008, p. 64). Tener fe implica confiar en lo desconocido que transita por fuera de las redes de nuestra razón demostrativa; implica querer el misterio pues mi propio sentimiento es misterioso: “.... el misterio del sentimiento, a saber, la ligazón invisible de mi existencia con los seres y con el ser por medio del deseo y del amor" (Ricoeur, 2011. p. 107). El misterio, como veremos a continuación, nombra tanto la fragilidad de un corazón inquieto como el ánimo por el que así, en su falibilidad emocionante, vive (Ricoeur, 2011. pp. 100-101).

Es tanto lo que tiene que ver la fe con la existencia como con aquello que la transpasa. Y, así, la fe trabaja desde ese sin-sentido que da sentido, aun no colocándose como meta o fin ulterior al sostén de la propia vida, que necesita ser también ultravida (no solo existencia sino esencia para la existencia). Ricoeur la explica, la fe, tomando matices en diferentes ámbitos. En el proverbio oriental, la fe trata de incardinarse en el sendero de la propia existencia, permitiendo orientar y discernir. En la cultura bíblica, el proverbio profundiza en paradojas e hipérboles. (Ricoeur, 2011b. pp. 76-79). Como sea, se abren dos dimensiones: la búsqueda de signos y la apertura a lo que nunca quedará agotado o desvelado por ellos. Como sabemos, desde la sabiduría humeana $^{3}$ hasta la tan distinta kierkeggardiana ${ }^{4}$, la fe procura la energía vital,

3 Como sabemos, Hume muestra en su obra cumbre, Investigación sobre el entendimiento humano, cómo la fe juega un papel primordial en la práctica humana. Si por razón fuera, nos quedaríamos en el impasse de la duda filosófica cuya virtud en tanto actividad intelectual, se transmutaría exceso si pretendiéramos funcionar en la urgencia de la vida o ni siquiera en el vivir cotidiano, a partir de su reinado. Si bien nada nos asegura que las cosas tal y como las conocemos seguirán ahí mañana, que el coche se detendrá ante la luz roja del semáforo, que un tornado no arrasará nuestra vivienda o que una teja no caerá funestamente rompiéndome la crisma, tal escepticismo paralizaría por completo nuestra acción y nuestras vidas, si no lo tomáramos, saludablemente, como escudo contra dogmatismos y supercherías racionalistas, sino también como guía para nuestro quehacer diario. Hume diferencia muy bien el mundo de la reflexión del mundo de la vida, en el que la fe constituye 
basada en la confianza que nos enseña a caminar entre el misterio. Asimismo, en ambos, el amor está más acá y más allá de la ética y así lo resume Ricoeur: "El mandamiento que precede a toda ley es la palabra que el amante dirige al amado: ¡Ámame! Esta distinción inesperada entre mandamiento y ley solo tiene sentido si se admite que el mandamiento de amar es el amor mismo, como si el genitivo contenido en el mandamiento fuera a la vez genitivo objetivo y genitivo subjetivo; el amor es objeto y sujeto del mandamiento; o, en otros términos, es un mandamiento que contiene las condiciones de su propia obediencia por la ternura de su reproche: ¡Ámame!" (Ricoeur, 2011b. p.38).

Ciertamente, si pienso en ese impulso, en el ánimo que necesito para levantarme cada mañana, sin cavilar, sin hundirme en los para qué, me doy perfecta cuenta de que no requiero tanto de la certidumbre de lo que me depara el nuevo día y ni siquiera de la seguridad en una total ausencia de riesgos y peligros, sino de la confianza en el misterio, en que dentro de la cálida familiaridad de lo destinado, habrá lugar para la sorpresa y los desafíos. No son los lances eventuales los que arruinan nuestro vigor sino la falta de confianza en que seguirán apareciendo. De ahí que resulten gozosas esas señales de la experiencia vivida que, como proverbios encarnados "reorienten desorientando" 5 . Pienso que resulta gozosa, incluso, la sensación de tomar parte de un destino que es comprendido solo a medias.

\section{Así, la pregunta por el sentido de la vida puede librarse del marco humanista}

la garantía de la energía y el dinamismo que nos mueve (Hume, 2004. Sección 5).

4 Es tan basta y profunda la reflexión de S. Kierkegaard sobre la fe y cruza a tal punto el total de su obra que resultaría siempre deficiente una anotación o cifra bibliográfica. No obstante, la fe como estado superior en el que se halla el ser humano, una vez ha transitado y superado los dictados de la mera ética para adentrarse en un terreno mistérico, aceptando la inseguridad moral, por sentirse parte de una superior conciencia o ultraconciencia, ante la que las normativas del hombre quedan diminutas y, así, pausadas, pudiendo resultar en la más grande acción aquella que sería señalada como vil ante la sociedad, se muestra abundantemente a partir del pasaje abrahámico en Temor y temblor (1987). En cualquier caso, nadie como Kierkegaard nos enseña la grandeza de la incorrección política, de las causas transcendentes batalladas más allá del bien y del mal cifrado por la estrechez del aquí y del ahora de la cultura humana y el brillo de quien sabe caminar entre la obscuridad, amándola, aun en la angustia. Ver El concepto de la angustia. (2013). Y dado que no queda lejos de nuestras investigaciones presentes, sin que lo hayamos abordado, es oportuno referir este libro de Kierkegaard titulado Las obras del amor (2006)que podemos encontrar en Ed. Sígueme. Salamanca, 2006, alojado en .http://www.sigueme.es/docs/libros/las-obrasdel-amor.pdf

5 Tomo prestada la expresión de P. Ricoeur (2008. p. 77). Añado también, recogiendo su entender, que no es extraño que el proverbio y la parábola reorienten desorientando, pues su lógica es su estilo y su estilo es el propio de la metáfora. Resulta interesante quebrar la común y escolar idea de que la metáfora se reduce a una analogía, a una matemática regla de tres que no aproxima sino que da cuenta de lo aproximado, revelando una proporción. Para ello nada mejor que el planteamiento de P. Ricoeur (1988. p. 25): "si la metáfora no consiste en adornar una idea con una imagen, si consiste más bien en reducir el choque entre dos ideas incompatibles, es en esta reducción de distancia, en este acercamiento, donde la semejanza desempeña un papel. En efecto, lo que está en juego en un enunciado metafórico es hacer aparecer un <<parentesco >> allí donde la visión ordinaria no percibe ninguna conveniencia mutua". Así, la metáfora está más cerca de la paradoja que de la simetría y más cerca de la iluminación religiosa que de la razón matemática y más cerca de la desproporción mistérica que de la imagen y semajanza del antropomorfismo teológico. 
(racionalista, individualista o incluso solipsista) para formularse desde la hermenéutica y antes que en ella, en la religación y en la celebración de la dependencia, es decir, del amor, de la heteronomía ${ }^{6}$ y de la confianza incondicional que lo funda, la fe. Asimismo, la comprensión del cristianismo puede librarse del marco personalista y, de nuevo y con más vigor, encontrar para la vida una razón más fuerte que la supervivencia y para la muerte un más allá que la use (y la burle): "Escuchar excluye fundarse. El movimiento hacia la escucha requiere por lo tanto un segundo despojamiento, el abandono de una pretensión más sutil y más tenaz que la del saber onto-teológico. Requiere el desasimiento del sí mismo humano, en su voluntad de dominio, de suficiencia y de autonomía. A tal desasimiento se aplica la expresión del Evangelio: <<Quien quiera salvar su vida, la perderá>>" (Ricoeur, 2008. pp. 94-95).

\section{La muerte como garantía de la verdad. El reconocimiento y la fragilidad afectiva.}

La niña que eligió la filosofía ansiaba tanto la verdad que muchas veces contempló la idea de dar la vida para mostrar la suya ante el cruel escepticismo paterno. Una suerte de dignidad e impotencia nos transitan tanáticamente cuando la verdad de nuestra vida es tan frágil y, al tiempo, tan profunda y segura, que no existe más demostración que la drástica entrega a la muerte. Como sabemos, vivir es tener algo por lo que morir: "Cuando la prueba de la convicción se paga con la vida, el testigo cambia de nombre: se llama mártir. Pero, ¿cambia realmente de nombre? Mártyr, en griego, es testigo (...) Que el testigo sea asimismo el acusado reclama otro análisis distinto. A saber, que la sociedad, que la opinión común, que los poderosos detestan ciertas causas, acaso las más justas. Es necesario entonces que el justo muera. Y aquí se alza un gran arquetipo histórico, el servidor sufriente, el perseguido, Sócrates, Jesús... (...) El testigo es el hombre que se identifica con la causa justa detestada por la muchedumbre y por los grandes, es quien, por esa causa arriesga su vida" (Ricoeur, 2011. p. 117) "Pero, sobre todo, se denomina testimonio a una acción, una obra, al movimiento de una vida, en tanto constituyen la señal, la prueba viviente de la convicción y la consagración de un hombre a una causa" (Ricoeur, 2011. pp. 94-95).

Hoy pasaría los 40 años la persona por la que empecé a estudiar psicoanálisis. Tal vez sería más acertado, aunque trágico, decir la persona por cuya muerte me decidí a estudiarlo a fondo ¿Por qué? Porque él lo hacía, para

6 En este caso debo indicar mi gusto por el uso del término heteronomía por oponerme con él a los discursos de la independencia, que considero discursos antipolíticos (antirreligiosos: antirreligadores) y destructures de la fantasía de conexión e incluso de la conexión misma y de la esencia del amor. Sin embargo, he de hacer notar, para guardar el rigor, que Paul Ricoeur, busca, en la línea que advierte en Heidegger, un más allá de la oposición entre autonomía y heteronomía, quizás muy afortanado y digno de estudio aparte. Este más allá está emparentado con el rescate de la conciencia como dimensión no reductible a la moral (frente a Nietzsche, Freud y toda la órbita postestructuralista) y que no se impone como realidad originaria ni como autodominio sino como justa diferencia, que permite al otro ser otro y no necesariamente un otro impersonal o un apelante que nos demanda desde estructuras de poder y control desencarnadas. Ver Ricoeur, 2011b. p. 102-107. 
comprenderlo a él, para comprender su muerte, para comprenderme a mí y para compensar el arrepentimiento por no estar a la altura, por no haber velado, en la parte que me correspondía, por el sentido de su vida, por haber despreciado la importancia de la desdicha y la responsabilidad que todos y una tiene en la búsqueda conjunta del sentido, por no haberme dado cuenta más que tardíamente, en la recuperación de la angustia infantil, de que vivir y morir, alegrarse y sufrir, no son asunto, como quiere la autoayuda, de uno mismo sino que en juego está el reconocimiento mutuo, la escucha de la verdad que el otro y prójimo nos ofrece, en definitiva, la generosidad. La generosidad es, en realidad, pienso ahora, anterior a la firmeza, pues no se puede exigir más firmeza a aquel al que, en su predicación, abandonamos, no recibiendo, auténticamente su palabra, no estando ahí, dejándolo con la palabra en la boca. A veces, si no siempre, se aprende muy cruelmente qué es el amor, qué es la amistad. Se aprende con la crueldad de la finitud y se aprende a partir de un arrepentimiento muy concreto: el de haberse traicionado a una misma, burlándose de la niña que fue burlada, de aquella que deseando expresar su verdad y no siendo tomada en serio, solo se le ocurría, mostrarla con el sacrificio de su vida. A veces los melancólicos nos ponemos altaneros cuando una ráfaga de levedad nos recorre y confundimos levedad con fortaleza. Pero por suerte, aunque ásperamente, la gravedad siempre vuelve para librarnos del absurdo y de una existencia vacía y descomprometida. Mi amigo, brillante, sabio, sensible y... desencantado, dio su vida para mostrar una verdad. Yo sé que esa muerte no fue vana sino terriblemente significativa. Un suicidio lleva un mensaje, al que muchos le dan la espalda pero no es esto sino cobardía pues es un mensaje religioso, es un mensaje social, político, es un mensaje de amor o para el amor. Hacer el amor es hacer hermenéutica porque hacer el amor es mantenerse a la escucha e interpretar para dejarse interpretar.

Pocos meses antes de su partida, conversando, me dijo dos cosas que nunca olvidaré y que han resultado clave para mí. Hablábamos precisamente del insomnio y del martirio que nos parecía madrugar, teniendo que levantarnos a toque de despertador justo cuando el miedo a perder la conciencia había cedido y nos encontrábamos abandonados al reposo. No queríamos dormir cuando ya habíamos logrado sobrevivir al día, pero tampoco queríamos despertarnos para enfrentarnos a uno nuevo. Yo me preguntaba por qué esa especie de inercia cíclica, por qué era tan costoso levantarse por la mañana, cuando había sido tan resistido el momento de acostarse. Todavía hoy entiendo que hay un morir en el dormir y un nacer en el despertar, que la idea de lo uno y de lo otro es altamente angustiosa, pues se trata de los hitos más dramáticos y esenciales por los que entramos en el tiempo de la sucesión, en la finitud, y porque nos vienen impuestos, hallándonos en ellos totalmente a merced del relato de cualquiera sin que tan siquiera tengamos derecho a enmienda. Pero entonces fue cuando su pregunta irrumpió, desorientando para orientarme: "¿Pero no te ocurría, cuando ibas al instituto, que esa pereza de despertar y levantarte desaparecía alguna vez, de forma muy especial cuando empezaba a gustarte un compañero de clase o un estudiante nuevo?¿No te despertabas entonces, pensando rápidamente en verlo, curiosa por saber qué pasaría ese día, si alguna nueva señal estaba al caer?". Al instante estuve de acuerdo en que así era y de que hasta su planteo apenas me había dado cuenta. Puede 
que desde entonces el deseo, el amor, fueran el tema filosófico de mi vida.

En otra conversación, poco después, hablamos del suicidio pues él aseguraba que el suicida, se suicida por venganza. En ese caso, había sido tan cierta esa sensación en las ideaciones infantiles de suicidio contra mis padres que me causó miedo o, lo que es lo mismo, rechazo a enfrentar quiebros aparentemente superados. Sin embargo, tenía razón pero la tenía a condición de aceptar que solo nos vengamos por amor, siendo la venganza un "hacer ver". Parece que solo la muerte podría demostrar a los que nos importan que nuestras protestas y demandas no eran frívolas. Quienes nos importan son aquellos a los que queremos importar y queremos importar a los que nos han seducido para pensar que su importar es el más importante importar. Las figuras paternas son paradigma en este caso (si bien es cierto que tanto podríamos usarlas como estructurantes de la experiencia amorosa, como estructurantes de algo bien distinto pero confundido con ella, tal como es la experiencia de poder, en cuyo caso habría que reivindicar, con Deleuze un amor por fuera del constructo edípico en el que hemos sido atrapados, pero también que un amor así podría ser un auténtico amor religioso). Sin su reconocimiento, pareciera que ni existimos. Es complicado lograrse una identidad y una estima sin reconocimientos paternales, y es complicado sentir el reconocimiento paternal por vías claras o sin pagar con una deuda infinita. En este complejo, diremos con Freud, se aprende el amor ${ }^{7}$.

La otra cara de la fe, del deseo apasionado que nos levanta de un salto, pereza conjurada, para ver si el amado nos mira, es la fragilidad afectiva. Paul Ricoeur le dedica un capítulo en Culpabilidad y finitud, acompañándose del espíritu de Inmanuel Kant y dice: "Detrás de la tercera pasión según la antropología kantiana, la pasión de <<honor>>, de gloria, aparece una demanda más originaria que aquella, la demanda de valer en la opinión del otro, la demanda de estima (...) En esta demanda de estima, late un deseo de existir, no mediante la afirmación vital de sí mismo sino gracias al reconocimiento gracioso del otro. Entre esa demanda de estima y la posición egoísta y solipsista de la vida, está toda la distancia que media entre el simple deseo y lo que la Fenomenología del espíritu, denomina el deseo del deseo". Esta demanda de reciprocidad, de la que no puede rendir cuentas ningún querervivir, constituye el auténtico tránsito de la conciencia a la conciencia de sí. Sin embargo, esta demanda no se satisface ni con las relaciones interhumanas surgidas con ocasión del tener, que son relaciones de exclusión mutua, ni con las relaciones surgidas con ocasión del poder, que son relaciones asimétricas, jerarquizantes y, por consiguiente, no recíprocas. Por eso, la constitución del Sí continúa más allá de la esfera de lo económico y de lo político, en la región de

7 El texto más expresivo y concentrado descriptor de tal proceso es de S. Freud: Duelo y melancolía. Podemos encontrarlo en compilaciones de textos tanto en Editorial Alianza, RBA y otras. También libre en http://www.philosophia.cl/biblioteca/freud/1917Duelo\%20y\%20melancol\%EDa.pdf. Si perseguimos una amplitud y enorme profundidad acerca de mencionado proceso de identidad y vivencias primarias del amor, debemos acudir a los estudios de Melanie Klein: Amor, culpa y reparación, recogido en el Tomo I de las Obras Completas de la autora en RBA. Barcelona, 2006. 
las relaciones interpersonales; allí es donde persigo el propósito de que se me estime, de que se me apruebe, se me reconozca. Mi existencia, para mí mismo, es tributaria de esa constitución en la opinión de los demás; la constitución de los sujetos es, por consiguiente, una constitución mutua mediante la opinión. Pero la fragilidad de esta existencia, en tanto que reconocida, radica en que la <<estima>> que la consagra sólo sea opinión, en que la timé sea doxa; está ahí la amenaza de una existencia especular y cuasifantasmática; esa posibilidad de no ser ya más que una frase del otro, esa dependencia de la frágil opinión son precisamente la ocasión para las pasiones de la gloria que injertan su vanidad en la fragilidad de la estima como opinión" (Ricoeur, 2011. pp. 137-138). Pero sabemos, con Ricoeur, que solo los seres capaces de conocimiento, son seres capaces de reconocimiento y así: "la estima de mí mismo que busco mediante el aprecio del otro no es de distinta naturaleza que la estima que yo le tengo a él" (Ricoeur, 2011. pp. 141).

Comprendamos a partir de aquí cómo lo que se presenta a menudo como síntoma de enfermedad no son sino episodios de la aventura del desamor, de la desasistencia, de la falta de receptividad, de la predicación en el desierto: "porque es creído, el valor del yo se puede fingir, alegar, aparentar; también se lo puede desconocer, contestar y denunciar; y también despreciar, vilipendiar, humillar; y cuando, con razón o sin ella, se desconoce, la falta de aprecio se puede compensar sobreestimándose a sí mismo o subestimando al otro y sus valores: agresividad, represalias, resentimiento, venganza, constituyen otras tantas respuestas al desconocimiento, que sólo comprendo por el afán de reconocimiento" (Ricoeur, 2011. pp. 142).

\section{Desproporción entre lo sagrado simbólico y la palabra interpretativa: reivindicación del misterio.}

Admitiendo felizmente mi persistente romanticismo, propongo que esa serie paralela de elementos que se encuentran puntualmente, en momentos kairóticos del camino y que, tomando a Ricoeur, se darían la mano como signos y misterio, se admita y comprenda también bajo los conceptos conjugados de naturaleza y cultura. Claro que se hace absolutamente imprescindible explicar que no estoy conduciendo nuestra problemática hacia la manida dicotomía antropológica pero sí, en cambio, disfrutaría dislocándola (y deslocalizándola), de tal modo que resucitemos la physis griega degustándola hasta su agenciamiento expresionista alemán, en el que también hace presencia el temor y el temblor, dando así a la cultura, no el carácter de envés de la naturaleza (o de freno o de represión) sino el de palabra que intenta atrapar, sin inmovilizar, los fenómenos que se nos antojan, por conveniente capricho, señales de una naturaleza nouménica, que aun siéndolo, nos interpela o, no haciéndolo o haciéndolo sin querer, nos invitara a una lectura flotante y nos dijera quién y qué somos y cuál es nuestro humilde papel dentro de su eterno discurso. Puede que haya un exceso del significante respecto de la referencia pero por ser esa referencia un constructo ya recortado por la expresión verbal ${ }^{8}$. Más bien destaca el inmenso exceso de la naturaleza, pues,

8 Cierto es que, comprendida la naturaleza como simbólica, como el propio Ricoeur afirma: 
repito, poniéndome mucho más romántica que hebrea, es en ella donde habita el inagotable misterio y así, la sacralidad: "Lo sagrado de la naturaleza se muestra diciéndose simbólicamente. El mostrar funda el decir y no a la inversa. La sacralidad es inmediata o no es" (Ricoeur, 2011. p. 71). La palabra, igualmente, puede y debe resonar en el templo en cuanto que solo ella puede dar cuenta mediática de tal inmediatez. Así, el verbo tiene su lugar en la hora del ritual de sacralización, como palabra mensajera y como palabra expropiada de sí. La Naturaleza es simbólica y enigmática; la palabra es metafórica y resuelve o indica el sentido de los enigmas: "El símbolo está ligado. El símbolo tiene raíces. El símbolo se une en la experiencia tenebrosa de la Potencia. La metáfora es sólo la superficie lingüística que debe a su bi-dimensionalidad el poder de religar lo semántico a lo pre-semántico en la profundidad de la experiencia humana" (Ricoeur, 1988. p. 28).

Este ecologismo mío, romántico, desde el que hablo, no pretende, contra el racionalismo ilustrado, que la naturaleza deje de resultarnos temible, sino que hallemos deleite en quererla terrible (tremenda) como es. Vuelvo en este punto a los recuerdos de infancia y me pregunto cómo sería posible, sin tal deleite, la infancia misma, que se me antoja ahora como conjunto de ensoñaciones inspiradas por los cuentos. El cuento me parece, por excelencia, el género literario que aborda, esencialmente, el misterio. El cuento nos devolvía la visión fantástica de los bosques a los niños de las sociedades industrializadas y nos traía esa noticia tenue de los lobos, de los osos y de los magos, brujas y monstruos, es decir, de esos personajes fronterizos que habitan en el medio de lo humano y lo divino, entre la luz de la luna y la obscuridad de la noche. Si un humano estaba en el bosque solo podía ser que anduviera perdido y buscando, entre la emoción y el miedo, un camino de vuelta, porque si un humano vivía en el bosque, no era del todo humano y si una casita se recortaba entre la espesura, sería, sin duda, una casita encantada. Perderse en el bosque es, quizás, nuestra primera imagen del viaje iniciático. En el cuento, los niños curiosos, atraídos por los frutos y recovecos y por la abundancia de la maleza, es decir, atraídos por señales indescifradas y por el deseo de encontrar escondites secretos alejados del mundo adulto del orden y del trabajo, pues los niños son, ellos mismos, personajes también fronterizos, iniciaban un camino aporético, irreversible, un camino que no permitía trazar huellas permanentes, como no se podían tampoco trazar, decían los griegos, en el mar $^{9}$.

Por eso en el cuento hay un proverbio, una moraleja siempre extraña y ambivalente. El cuento es la historia de una enseñanza de la naturaleza que se manifiesta y de un aprendizaje propiciado por la subrayada irreversibilidad del camino de ida, o dicho de otra manera, porque el camino de retorno nunca podría ser una simple inversión del primero sino otro, lleno de desvíos y de desvaríos, que nos devolvería a casa con la sabiduría insólita y extranjera de un encantamiento, con unos conocimientos que aparecerán ante los adultos

"ninguna categorización dada da cuenta de las potencialidades semánticas tenidas en suspenso en el símbolo, pero es únicamente el trabajo del concepto el que puede testimoniar este exceso de sentido" (1988. p.29).

9 Tengamos en cuenta el significado etimológico de aporía: sin camino, siendo que así se denominaba el lugar por donde no hay pasaje o en el que no puede marcarse una senda. 
como quimeras y despropósitos de un niño que, tras los años, dudará, habituado de nuevo al interior de la caverna, de la propia realidad de aquel viaje. Así se cuenta la historia del inconsciente, de lo otro, de lo salvaje, de la fantasía (incluyamos la fantasía de conexión que hace que bajo el embrujo del amor, digamos: "estoy viviendo en un cuento de hadas"; y que enseguida nos imaginemos exiliados en un paraíso de playa y mar o de cielo y nubes...). El cuento es la intersección de la palabra y la naturaleza, una intersección en la que tratamos, con los personajes, de leer una naturaleza que no se deja textualizar del todo, ni para el escritor del cuento, que no logra eliminar la sospecha infantil de estar siendo engatusado por historias y relatos, ni para los protagonistas, cuyos "cuadernos de bitácora", inversamente, no son tomados en serio por el mundo de los adultos. En el cuento, la fe está en juego y en el juego de orientación y desorientación está la fe.

Se diría que el cuento replica el mito de múltiples formas. Por un lado, ambos tipos de narración relatan un regreso desde la vivencia del "otro lado". Pero, además, el cuento, propio de los tiempos modernos, nos translada a eso otro que en el tiempo de los antiguos mitos preindustriales, no era todavía lo otro. Incluso podríamos ensayar la siguiente perspectiva: el cuento constituye, con respecto a los mitos, un futuro anterior, pues si en el mito, a menudo, se describe la fundación de una ciudad, en el cuento se novela la huida de la ciudad y el adentramiento en lo que pareciera, sea fábula o no, lo previo, lo que era antes del dominio humano. En todo caso, el primitivo, el niño, el loco y, así también, el religioso, por ser premodernos, no habrían olvidado aún el universo de lo sagrado.

La desacralización es tan indeseable para Paul Ricoeur como lo fuera para Friedrich Nietzsche o Martin Heidegger, pero, quizás más optimista en cuanto a la posibilidad de mediación, ya entre la conservación de lo sagrado y la revelación cristiana, ya entre la conservación de lo sagrado y la política crítica, o, dicho de otro modo, los movimientos de liberación. Ricoeur nos alivia así: "La modernidad no es un hecho ni un destino, es una cuestión abierta" (Ricoeur, 2011. pp. 82); y sobre todo con este hermosísimo interrogante: "¿Se puede acaso vivir sin orientación originaria? ¿O sólo es un fenómeno residual o una protesta existencial venida de las profundidades, la que nos empuja a la búsqueda de lugares privilegiados, sea nuestra patria de nacimiento, la escena de un primer amor, o el teatro de algún gran hecho histórico -batalla, revolución, ejecución de patriotas...? Volvemos a esos lugares porque allí otra realidad distinta de la cotidiana había hecho irrupción y porque el recuerdo que vincula el acontecimiento con ese lugar nos preserva a todos de convertirnos en seres errantes ¿Pueden los actos de construir y habitar quedar enteramente desacralizados sin perder toda especie de significación? ¿Es posible abolir la simbólica del umbral de la puerta, del hogar y todo ritual de ingreso $y$ acogida? ¿es posible desacralizar enteramente el nacimiento -venida al mundoy la muerte -ingreso al lugar del reposo? ¿Es posible despojarlo de todo rito de pasaje sin degradar enteramente al hombre, convirtiéndolo en un utensilio; sin exponerlo sin resto a una manipulación que concluye con la liquidación de un desperdicio? ¿Es posible abolir todos los ritos de iniciación restantes sin que los $<<$ pasajes>> de la vida se conviertan en simples transiciones 
insignificantes? ¿Y la sexualidad no deviene totalmente insensata cuando se rompe todo vínculo entre ella y el gran juego de las uniones cósmicas? ¿El tiempo de la repetición, despojado de toda ritualización, puede acaso ser otra cosa que una figura de la condenación? ¿Hay acaso algo más paralizante que el eterno retorno sin regeneración? ¿Es posible vivir en un tiempo sin fiestas, según un calendario absolutamente profano? Por último ¿es por casualidad que lo que en América se llama <<subcultura >> se encuentre desesperadamente en busca de la fiesta en comunicación con fuerzas de la naturaleza que de nuevo se comenzarían a admirar, sin explotarlas? Tales son las nuevas cuestiones que empezamos a plantear, más allá de la muerte de lo sagrado ¿No nos encontramos en las vísperas del renacimiento de los sagrado, si a pesar de todo el hombre está llamado a sobrevivir? (Ricoeur, 2011. pp. 82-83).

\section{El sentido de la muerte como respuesta a la pregunta por el sentido de la vida.}

La fantasía de conexión es una dimensión paradigmática de lo sagrado pues, como decíamos, solo en ella perdemos el miedo a la muerte sin dar la espalda al dramatismo de su realidad y sin evadir la pregunta por la crueldad de la finitud. La fantasía de conexión es la vivencia efectiva de la confianza incondicional que denominamos fe. La fe es moral y es política: el que carece de fe, de impulso vital, de vigor sin cuestionamientos, de compromiso con la causa antes que con cualquier otro cálculo, anda por la vida errante, lento, aturdido, anda, se dice, desmoralizado. La política solo es política a condición de perseguir e insistir en lo unitivo del lazo social, es decir, a condición de concrear comunidad, que no mercado. A fin de cuentas, hacer política es también hacer el amor, dado que siendo la justicia la piedra angular de la política, ¿qué es el amor sino la más básica y espontánea de las justicias? El amor es la justicia que se vive en la inmediatez y no en la reparación ${ }^{10}$. Todo los cálculos

10 También podríamos distinguir justicia y amor diciendo que solo se requiere justicia porque hay algo a lo que hacer justicia, algo a lo que se ama, algo en lo que hay que tener fe, o hacia lo que nos mueve la fe: "Ni las circunstancias de la justicia ni sus vías son las del amor. Todavía menos los argumentos de la justicia son los del amor. A decir verdad, el amor no argumenta..." (Ricoeur, 2011b. p. 42); "La economía del don desborda por todas partes a la ética. Todo un abanico de significaciones confiere una articulación específica a esta economía del don. En un extremo de este abanico nos encontramos con el simbolismo, él mismo muy complejo, de la creación, en el sentido más fundamental de donación originaria de la existencia..." (p. 47); "la economía del don desarrolla una lógica de sobreabundancia que, en un primer momento al menos, se opone polarmente a la lógica de equivalencia que gobierna la ética cotidiana" (p. 48-49); "El hombre entra en el mundo ético por el miedo y no por el amor" (Ricoeur, 2011. p. 193). Creo que esta distinción de Ricoeur es la que retoman o expresan también, a su modo, los filósofos de las políticas del amor y de las políticas estéticas. Pero a pesar de las simplificaciones escolares, ya en Kant se prefigura esta idea, tan propia de Bataille, del deseo como primero respecto de la razón, del don como lógica anterior a la de la justicia, y de la religión como verdadero corazón de la política. Ricoeur trata de recogerlo en su estudio sobre la síntesis práctica, con la siguiente aseveración: "El principio será solo práctico si el deber conmociona al querer" (p. 92). La vuelta moralista y la insistencia en la doblegación y fulminación del deseo se encuentra también, imposible de evadir, en otros pliegues del carácter kantiano. En ese punto Ricoeur toma distancia, pues como sabemos, en él, el saber divino se diferencia del todo de la pretensión diabólica de 
y análisis que caen fuera de la fe, en el ámbito de una pura razón, juegan su papel como elementos tácticos, más la auténtica estrategia se halla en la fe, en la convicción, en el deseo vital: "creer es afirmar y afirmar es <<hacer>>" (Ricoeur, 2011. pp. 51).

Así da cuenta Ricoeur del sentido de la teología política hallando en el cristianismo la poética de la política o, lo que yo he estudiado en otras ocasiones como ontología política: "Ciertamente, la existencia humana es existencia política. Pero los textos en los cuales la existencia cristiana se comprende a sí misma sólo son políticos en la medida en que son poéticos. De modo que los modelos para una familiaridad entre Dios y su pueblo y el resto de los hombres constituyen más bien lo que denominaría una poética de la política que, para recibir una cualificación propiamente política, reclama ser articulada en análisis, saberes, intereses, organizaciones, etc. Para emplear un lenguaje weberiano, diré que esos modelos no alcanzan la política sino nutriendo una moral de convicción, imposible de reducir a la mora de responsabilidad que, no lo olvidemos, es asimismo la del uso limitado de la violencia" (Ricoeur, 2011. p. 107) De este modo, podemos retomar la comprensión de la muerte como consagración de la vida, siendo la muerte la que sacraliza la vida tal y como el profeta, siendo el poeta de la política, ejemplifica en su convicción, con su fe e inmediatez y con el trabajo de dar algo para la interpretación, tanto en su vida como con su muerte, que deviene, asimismo, signo: "todo profeta, en la medida en que profetiza contra, es profeta para la vida y para la muerte" (p. 119). El profeta es poeta, ya que siendo el que resuelve enigmas activamente, genera sentido al modo de la metáfora (Ricoeur, 1988. p. 26).

Una teología política trae la naturaleza, la Potencia, al campo de lo social, a través de la acción humana con sentido, si bien con un sentido despsicologizado en tanto los actores desconocen la trama. El saber del desconocimiento marca la dimensión religiosa. La fe impulsa el hacer, el cumplir queridamente bueno de un papel, de nuestro papel, en el que tratamos de interpretar signos, ser interpretados por dicho interpretar y convertirnos, a su vez y en el mejor de los casos, en signos que troquelarán el rumbos de otros, las interpretaciones y reinterpretaciones de los demás. El otro que se nos viene en modo de afecto, en modo de textos, en modo de habla, en modo de movimientos, en modo de hábitos, nos permite situarnos, aunque semialeatoriamente, en ese universo sagrado que co-construimos. No es necesario, en cambio, liderar masas ni rodearse de todo el mundo en el momento periodístico, para cumplir políticamente. Es posible, de entre las maneras, el juego político en el retiro, sobre todo, es posible a tenor de los ciclos y de la consideración de los mismos: "La llamada aísla; el envío religa" (Ricoeur, 2011b. p. 87), pues no es del todo posible distinguir el papel de unos y de otros o hasta dónde llegó la acción de ellos y desde dónde comienza la mía. Por suerte, nuestros actos escapan a las simples intenciones propuestas.

sentar y clasificar según lo que de antemano es el bien y el mal, y lanza su particular apuesta: "la reflexión transcendental se sitúa de entrada en el nivel de lo originario, sin tener que alcanzarlo a través de una condición depravada" (p. 96). 
Es por ello que pasan a formar parte de los signos y de los acontecimientos: "el tiempo social no es solo algo fugaz; es también el lugar de los efectos duraderos, de pautas persistentes. Una acción deja una huella, pone su marca..." (Ricoeur, 1988. p. 66).

La muerte es, para un ser finito, es decir, para alguien que no es un dios, la única prueba que puede dar de una verdad que lo excede, es la única comunión definitiva con lo divino, con lo otro. A menudo se critica como impostura el ritual ensalzamiento del fallecido, diciendo burlonamente: "Resulta que cuando uno muere, siempre era muy bueno, muy bueno" o "cuando uno muere, todo de él eran virtudes", etc. En cambio, no advertimos que los rituales suelen esconder un sentido ${ }^{11}$ que, por olvidado, no deja de resultar reconfortante y es que la muerte constituye una donación, querida o no o, más bien, conscientemente querida o no, una ofrenda, un sacrificio que, como tal, constituye una prueba. El que muere es el que lleva su verdad hasta el final e, inversamente "una verdad que no captura al hombre hasta el sacrificio carece de prueba" (Ricoeur, 2011, p. 130). La muerte es una tragedia y, como tal, igual que en su acepción literaria, ennoblece:"la tragedia es una imitación de las acciones humanas que las hace parecer mejores, más elevadas..." (Ricoeur, 1988. p. 55). En este punto, nos encontramos en condiciones de contestar al por qué de la crueldad de la muerte y de calmar la búsqueda del sentido de la vida trocando, precisamente la pregunta por el sentido de la vida en búsqueda de sentido para la muerte. Pienso ahora que tal vez la vida es un preguntar, mientra que la muerte es, o debemos hacer que sea un contestar. Quizás si la muerte es contestataria, haya una esperanza para la transcendencia. Al fin y al cabo, el infinito es, para el humano, una transgresión vivida como intención de significar.

\section{Lo infinito como transgresión: el deseo humano de significar.}

Siempre me llamó la atención la cuestión del pecado original y ni en mi fase más atea pretendí ni quise disolver tal interrogante de modo vulgar, condenando, por ejemplo, a las religiones por tratar de infundirnos una culpa que nos desacreditara como dueños y señores de nuestra existencia o porque nos impidiera protestar ante un destino cruel y no elegido o porque nos impeliera a la sumisión apropiada de quien tiene que pagar por un agravio del que se es autor, aun en la ignorancia. Siempre tomé la cuestión del pecado original como un enigma en el que se albergaba una verdad porque la sentía: sentía algo de eso, sentía que algo así como una pena (o dígase malestar si se prefiere el vocablo freudiano) recorría nuestra existencia: una pena o una responsabilidad originaria o algo que liga a una y la otra cosa o que las hace ser lo mismo.

Pudiera ser esa pena la que se paga por la culpa de haber nacido y que se compensa con la muerte. No se indica tanto una culpa en la sentencia

11 "El prejuicio contra el prejuicio procede en efecto de un prejuicio profundamente arraigado contra la autoridad, que se identifica demasiado rápidamente con la donación y la violencia" (Ricoeur, 1988, p. 156). 
retomada por Anaximandro, sino una deuda ontológica, la de romper con la unidad del Ser para ocupar un lugar y un tiempo. En todo caso me interesa destacar que esa deuda ontológica que se vive como un cierto dolor ${ }^{12}$, bien se presente a modo de angustia apremiante, bien se quede en una segunda pantalla, haciéndose casi imperceptible, nos permite presentir el puente vinculante entre el nacimiento y la muerte $y$, tal vez incluso, se ofrezca como el recuerdo de la desventura, de la ansiedad, del quebranto... del primero, y como la expectativa fúnebre de la segunda, que, al modo de cualquier susceptibilidad fóbica, nos atemoriza y atrae o nos atemoriza como lo hace siempre un fuerte deseo inobservante.

El vértigo me parece la fobia por excelencia: la atracción y terror hacia el abismo. Al abismo no se llega ni, por supuesto, se asciende a él. En el abismo se cae. Su llamada no abre un camino, y ni siquiera un viaje aporético como el de los cuentos, sino que su llamada pide precipitación, un salto arrojado e irreflexivo al vacío. Tengo el convencimiento de que así se siente el nacimiento (y en esto me apoyan muchas voces de autoridad dentro de la filosofía en incluso de la ciencia) y de que, desde esa precisa impronta imaginamos también la muerte ${ }^{13}$. Puedo que solo tengamos miedo a la muerte por lo abismático que fue el nacimiento, más sabiendo, por los cuentos, que los caminos de vuelta son todavía más retorcidos y atorados que los de ida. Continuando, por un momento, la analogía con el cuento, algo más hay seguro, más seguro si cabe: en el medio entre el emprendimiento y el retorno se produce la sensación de estar perdido. El nudo del cuento aparece justo en ese punto en el que el protagonista se da cuenta de que se ha perdido ¿Por qué entonces habría de sorprendernos el sentirnos perdidos? ¿Por qué, de hecho, lo tomamos como trastorno, siendo tal vez la esencia del estar vivo, humanamente vivo? Pues vivimos, estamos perdidos. Así el Evangelio tan reseñado por Paul Ricoeur, "el que quiera salvar la vida, la perderá", toma, me parece, nueva luz.

Caer al vacío es un sueño típico en el recién dormirse. Muchas veces nos avisó, eléctricamente, de que morimos así en la vigilia y nacemos al sueño, cambiando por ello, la orientación y estilo del argumento. Caemos en el sueño y caeremos, pensamos también entonces, en la muerte, pues se dice de la muerte "el sueño eterno". Curiosamente también con sueño significamos ambición, anhelo, aspiración. Y, ¿no es la ambición sino ansia de eternidad, de anclar en la Memoria? ¿Cuál es, pues, tu sueño? Sin duda, debe ser el sueño

12 Esa juntura precaria, esa Diferencia unitiva es lo que Heidegger denomina "dolor". En la misma línea, Bataille, siguiendo al Freud de Más allá del principio del placer, denominará pulsión de muerte al "instinto" de reconstruir el tejido de la continuidad ontológica. Deleuze sitúa ese dolor ontológico en las grietas de las superficies que comunican el interior de lo ente con su Afuera constituyente. En cierto modo, podemos decir que en las superficies tiene lugar la diferencia ontológica.

13 Consideremos por un momento ese relato tan repetido por aquellos que sufrieron una muerte clínica fugaz ¿Por qué pensar que todos inventan esa historia acerca del túnel obscuro a cuyo término se avista una luz? No es más fácil pensar que se produce un rememoramiento de sensaciones natales? Pues, ¿no parece lógico que el bebé, que sale de la obscuridad por un conducto estrecho y obscuro, sienta por vez primera una luz casi cegadora al final, una luz que lo atrapa y trae hacia sí? 
eterno. No sé si queremos morir, a condición de significar o queremos significar para poder enfrentarnos a la muerte, pero, consciente de que esta segunda posibilidad parece más a tono con el sentido común, quisiera hacerme cargo más bien de la primera, pues retomando las reflexiones anteriores en torno al impulso tanático que inunda nuestra impotente impaciencia por mostrar la verdad, en torno a ese recurrente "doy la vida por...", y siempre conocedora de que la filosofía le hace la batalla al sentido común, se me antoja una línea más interesante y esclarecedora.

Durante mucho tiempo creí, en cambio, que el pecado original tenía un carácter más epistemológico-ético que ontológico. Me subscribí a la que me parecía la incuestionable y únicamente válida interpretación del pecado original: el pecado original como metáfora de la pérdida de la inocencia. Estimo oportuno detenerme unos momentos en ella pues recién es que avisto otras perspectivas que aún no sé si sustituirán a ésta o más modestamente, la complicarán. La pérdida de la inocencia es la condición humana misma. Se trata de una pérdida inevitable, irrevocable e irrenunciable. Es por eso que aún adscrita a las filosofías postestructuralistas del deseo, en la reivindicación de la inocencia, no encontré sino la auténtica dirección para mi ecologismo (que no es poco), para mi animalismo (que no es poco), para mi religión, a saber: el respeto por el misterio, la reivindicaión de la conservación de lo sagrado y la idea de que los animales salvajes, por no ser buenos ni malos, son más buenos que nosotros. Pero, en la proximidad con los perros, que son medio animales medio humanos, encontré la fascinación por lo divino humanizado, por el mensajero de los dioses mistéricos, de los lobos, que viniendo a vivir entre nosotros, nos traían su legado para que lo entendiéramos, o mejor, para que intuyéramos la legitimidad de la fe, la razón de la fe. El perro ya no es salvaje pero procedente de lo salvaje, parece exhibir lo mejor de lo humano. Y así la figura de Cristo, tan semejante, dejó de parecerme la antropomorfización y conjura de lo divino para parecerme la figura del puro amor y de la entrega, del que da la vida para mostrar una verdad que solo con tan enorme sacrificio puede mostrarse ante la condición precaria del ser humano, ante lo que Paul Ricoeur, en su reecritura de Platón, denomina la miseria, lo "patético" de la miseria: "En efecto, es la situación misma del alma la que es miserable; en la medida en que es, por excelencia, el ser que se encuentra en el medio, no es la ldea; como mucho, es $<<$ de la raza de las ideas $>>$ y de lo que está <<más próximo >> a la idea; pero tampoco es una cosa perecedera: su cuerpo es lo que <<más se parece>> a lo corruptible; el alma es más bien el movimiento mismo de lo sensible hacia lo inteligible; es la anábasis, la ascensión hacia el ser; su miseria se muestra, ante todo, en estar perpleja y en buscar" (Ricoeur, 2011. p. 27).

El pecado original como pérdida de la inocencia o, si se quiere, como toma de conciencia, se relata en el Génesis, a mi parecer, de hecho, de modo inmejorable. La tentación diabólica del fruto del árbol del conocimiento constituye la entrada involuntaria en la moralidad. Este fruto se registró en el imaginario como manzana, al resonar con las manzanas de la mitología (las manzanas de las Hespérides, la manzana de la discordia disputada por Hera, Afrodita y Atenea...) y al repetirse en innumerables cuentos (Blancanieves, Guillermo Tell, Hansel y Gretel...) o quizás, dicen, por el parecido entre los 
términos latinos malum (manzana) y mali (mal). A este imaginario podemos añadirle otro sedimento definitivo: el de la manzana de Newton, pues ese árbol de su relato es, sin duda, un árbol de la ciencia. Con las manzanas se prometía la inmortalidad pues, en las representaciones del mal, un diablo nos convence de que conocer es lo mismo que ser y que, conociendo los secretos del eterno Dios, sabremos cómo alcanzar su misma eternidad. Sin embargo, las manzanas prometían inmortalidad a aquellos que no sabían de su mortalidad, a aquellos que ya eran eternos o vivían como eternos, si no fuera porque en un mismo momento, la promesa de inmortalidad arruinaba y auguraba una eternidad reflexiva. Una eternidad así, de segundo grado, traída de la meditación es sospechosa, pues justamente la inmediatez define la eternidad. A cambio, se abre la dimensión religiosa, desde lo patético de la miseria y hacia la transgresión de la propia condición humana; se abre el deseo de salir de la insignificancia para significar y tener un sentido, el de un interrogante que se abre con el nacimiento y se cierra con la muerte: "Pertenece, pues, a la finitud humana no poder experimentarse a sí misma más que bajo la condición de una <<visión-sobre >> la finitud, de una mirada dominadora que ya ha empezado a transgredirla"; "Este discurso completo sobre la finitud es un discurso sobre la finitud y sobre la infinitud del hombre" (Ricoeur, 2011. p. 42).

Pero el humano es humano porque conoce, así que el patetismo de la miseria le es inevitable y el conocimiento es el peor de los males por radicar la distinción entre el bien y el mal, y es el mejor de los dones porque solo conociendo nos aproximamos a ese Dios que no podemos ser y porque, entonces, tenemos la oportunidad de ser buenos por determinación y no por casualidad, al distinguir entre el bien y el mal. En cualquier caso, una evidencia quedó popularmente obscurecida: en el relato bíblico no es Dios sino el diablo el que instaura el orden moral. Lo que no queda claro es si lo diabólico colabora en la trama de algún plan divino, es decir, si el hombre como ese ser distinto de los animales creados por Dios, es una producción también de Dios o del diablo o de los diabólico de la autoconciencia. No obstante, como decíamos, la pérdida de la inocencia es irrenunciable y una vez que nuestra curiosidad ha mordido el anzuelo, ya no podemos, sino por imposturas y perversas maniobras, volver al estado de inconsciencia. Podemos, tal es la invitación de Deleuze, deconstruir los códigos, pero no creamos, como solicita, que es viable hacerlo al margen de la idea de la transgresión, es decir, inocentemente. Una cosa es desestructurar los códigos y otra muy distinta y casi contraria es fingir que no los conocemos. No sé si un esquizo puede hacerlo pero una esquizofrenia no se auto-induce ni es, como el propio Deleuze indica en Lógica del sentido, una recuperación de la niñez (Deleuze, 1989. Decimotercera serie). En este aspecto concreto, mantengo con Sartre, que no darse por enterado es la más vil de las malicias. Necesitamos un proyecto ético y volver a la inocencia (a la inconsciencia) no es una opción ${ }^{14}$ : "Por <<débil>>,

14 Según Bataille, el ser humano no vive fuera de la animalidad sino más bien en un lugar situado entre el deseo de volver a ella y la imposibilidad de cumplirlo. La libertad humana o, mejor dicho, la libertad que el humano persigue no puede ser ya la vuelta al mundo apetitivo del animal, del mismo modo que la violencia humana no puede volverse hacia atrás y participar de la violencia inocente del animal. Tenemos que contentarnos con una animalidad rarificada, encontrada en el camino de vuelta, que no repite el de ida sino 
$<<$ impotente >>, <<inconstante>> y <<ridículo>> que sea, el hombre no deja de llevar la carga de conocerse: <<Estar lleno de defectos es, sin duda, un mal; pero es un mal todavía mayor estar lleno de ellos y no quererlos reconocer, pues esto es añadir asimismo a los anteriores el de una ilusión voluntaria (fragmento 100 de los Pensamientos de Pascal)>>" (Ricoeur, 2011. p. 33).

Retomaré, sin embargo, la cuestión del pecado original tomada desde aquel otro lugar, tal vez vecino, pues si nos centramos en el conocimiento para comprenderlo, no sabemos ya si hablamos de una caída o si hablamos de una ascensión, del mismo modo que queda desdibujado, borroso, si la adquisición de la moral es una caída o es una ascensión. Supongo que es una caída respecto del principio, de la inocencia del no-saber del bien y del mal, y un ascenso respecto del ya-saber del bien y del mal. Pero si la adquisición de la moral se da ahí, en el medio, es, de nuevo, un nombre del estar perdido. Ciertamente, los protagonistas de los cuentos se hallan perdidos entre el viaje de ida y el de vuelta, en el momento en el que tras una aventura de descubrimientos, comprenden que dichos descubrimientos no sirven para volver a casa más que, en todo caso, reinterpretados como signos en un metarrelato. Entre tanto, están perdidos.

Puede que aquella angustia de la que hablaba, aquel dolor que en primer o en segundo plano, nos acompaña, provenga de un saber de la muerte: "la maldición no es que el hombre muera (<<pues eres barro y volverás al barro> sino que afronte la muerte con la angustia de la inminencia: la maldición consiste en la modalidad humana del morir" (Ricoeur, 2011. p. 390). Sin embargo, ya está ahí desde el nacimiento, desde antes del conocimiento y desde antes del conocimiento de la muerte. Podría ser entonces, una anticipación solo intuida de la muerte pero ya fijé, de todas maneras, que muy probablemente, la expectativa dolorosa de la muerte se produzca porque se calca de la experiencia dolorosa y ya vivida del nacimiento. $Y$ es que el nacimiento rompió la certeza de nuestra primera fantasía de conexión, depositándonos en esa independencia que toma el humor de un desmembramiento: "la tristeza de lo finito (...) se alimenta de todas las experiencias primitivas que, por decirlo así, implican la negación: carencia, pérdida, temor, pesar, decepción, dispersión e irrevocabilidad de la duración..." (p. 157). No es la muerte la que nos arrebata, en primera instancia, la eternidad, sino el nacimiento, pues con él resulta que no fuimos siempre, que tenemos una perspectiva concreta y no todas a la vez y que nuestra génesis está depositada en el relato de otro: "Mi nacimiento me habla, por lo demás, de mi existencia como de algo recibido; no sólo como algo que me encontré ahí, sino como algo que me dieron otros; he sido traído al mundo, desciendo de mis padres; ellos son mi ascendencia; sin embargo, ignoro lo que significa esta donación que me convierte en heredero de mi propia vida. Aquí, más que en ninguna parte, es donde me acecha el vértigo de la objetivación" (p. 81); "El

añadiéndole una sensación de caída, de pecado, de transgresión. La animalidad recuperada ya no es la pura animalidad: ya no tiene el sentido de la "libertad" sino el de la transgresión: "La superación de una situación no es nunca un retorno al punto de partida. En la libertad está la impotencia de la libertad" (Bataille, 2007. p. 134). 
punto de vista es el ineludible estrechamiento inicial de mi apertura al mundo. Pero esta necesidad no es un destino externo; no se convierte en tal sino por medio de una falsificación, cuya andadura es fácil rastrear. No distingo dicho estrechamiento de mi apertura misma sino relacionándolo, mediante una nueva regresión más allá de todos mis <<desplazamientos>> pasados, con un primer lugar que coincide con el suceso de mi nacimiento. He nacido en algún lugar: $<<u n a$ vez puesto en el mundo>>, en adelante percibo ese mundo mediante una serie de cambios e innovaciones a partir de ese lugar que no he elegido $y$ que no puedo recuperar en mi memoria. Entonces, mi punto de vista se desgaja de mí como un destino que gobierna mi vida desde fuera" (p. 41).

El acontecimiento del nacer resulta, si recapitulamos, ontológicamente "injusto", experiencialmente fracturador, cósmicamente arbitrario, físicamente doloroso y biográficamente ajeno. No es extraño que lo imaginemos acompañado de una mancha y de una condena. Podríamos llegar a decir que no nacemos con el pecado original sino que nacer es el propio pecado original. Para comprenderlo bien, debo traer las clarificaciones de Ricoeur sobre el pecado: el pecado original no es individual sino que yace junto a la condición de expropiación del propio núcleo personal ${ }^{15}$; el pecado se encuentra más cerca de la pena que de la infracción, es decir, se revela indirectamente a consecuencia de la enfermedad, del sufrimiento por causalidad inversa. Pues no se esperaba como castigo, abre un interrogante acerca del sentido en medio de un sentimiento de caos, de pérdida y desorientación. "el pecado, en tanto que alienación consigo mismo, es, tal vez más que el espectáculo de la naturaleza, una experiencia sorprendente, desconcertante, escandalosa: como tal, es la fuente más rica del pensamiento interrogativo. En Los Salterios babilónicos más antiguos el creyente pregunta: << ¿Hasta cuándo, Señor?, ¿contra qué dios he pecado?, ¿qué pecado he cometido?>> El pecado me torna incomprensible a mis propios ojos; Dios está oculto; el curso de las cosas ya no tiene sentido ( $p$. 173); " la experiencia más conmovedora del hombre, la de estar perdido en tanto que pecador, conecta con la necesidad de comprender y suscita tomar conciencia por su carácter mismo de escándalo" (p. 174).

La culpabilidad no es un "tener la culpa". Por eso me interesa el pecado

15 Debería matizar que, según Paul Ricoeur, la concepción del pecado y de la culpa pasa por varios estadios, tanto en el sucederse de las interpretaciones religiosas como en el propio paso del pecado original, más antiguo en el relato y más primario en la vivencia personal, al pecado como mal a evitar mediante la sospecha de sí, con lo que se inicia la reapropiación del proyecto y significaciones vitales. La culpa individual es más laica que religiosa pero la obra de la propia vida y la convicción que la impulsa, que es fe, perteneciendo también a la religiosidad, pues se trata de recuperar dentro de sí mismo, la mirada absoluta, constituyen el índice de una teología ético-política. En todo caso, tal programa exige de la religación, de lo que hemos denominado fantasía de conexión, que implica unidad, también en la rendición de cuentas: "No se trata de negar que la imputación personal de la culpa marca un adelanto con relación a la escandalosa responsabilidad colectiva que permite castigar a otro que al culpable. Pero hay que entender que el precio de este adelanto es la pérdida de la unidad de la especie humana, congregada <<ante Dios>> por el vínculo más que vital y más que histórico de la culpa: el pseudo-concepto de pecado original no es más que la racionalización de tercer grado, a través del mito adámico, de ese vínculo enigmático, confesado más que reconocido en el <<nosotros>> de la confesión de los pecados" (Ricoeur, 2011. p. 243). 
original, ese en el que estamos todos por ser finitos, humanos, por tener una perspectiva limitada y querer dar cuenta, sin embargo, del infinito y querer no estar solo en nosotros mismos sino con lo demás. En esa mezcla de particularidad y apertura se abre el pecado común y la experiencia de la culpabilidad, no como culpa sino como deseo de rendir cuentas a algo más grande que nos supera. Dice Ricoeur: "La culpabilidad es la toma de conciencia de esta situación real $y$, si puede decirse, el <<para sí>> de esa especie de <<en sí>>" (p. 258).

A veces resulta molesta o angustiosa pero, tal vez dar la espalda a esta sensación que nos recorre no es lo preferible. Puede que tratar de entender esa sensación de culpabilidad flotante, que a menudo se ha tildado demasiado prematuramente de neurótica, sea lo más sano, pues de ese modo podremos comprendernos mejor o hallar en ese dolor algo de nuestra esencia, de nuestro particular modo de habitar el mundo. Heidegger, por ejemplo, más allá de psicologismos, atendía al dolor ontológico como aquello que se da en la juntura, en la superficie que nos une y separa, en el abismo interno de la simultánea soledad y compañía, en lo que une y diferencia, en la religación: "El dolor en el desgarro es lo unitivo que reúne y separa. El dolor es la juntura del desgarro. Ella es el umbral. Ella lleva a término el Entre, el Medio de los dos que están separados en él. El dolor junta el desgarro de la Diferencia. El dolor es la Diferencia misma" (Heidegger, 2002. p. 20). Se trata del dolor que tiene lugar en cuanto que lo vivo se desprende del apeiron, se trata de un dolor ontológico: "... toda angustia de la desintegración no es, en verdad, más que la única semblanza (...) en la que se oculta lo "verdadero": el dolor universalmente repartido y por siempre duradero. El dolor no es así ni repugnante ni útil. El dolor es la benevolencia de lo esencial en toda presencia" (p. 49).

La religión se rompe cuando concebimos la culpabilidad, de modo laico y unidimensional, como responsabilidad individual por los actos defectuosos o malintencionados, cuando "la metáfora del tribunal invade todos los registros de la conciencia de culpabilidad; pero antes que una metáfora de la conciencia moral, el tribunal es una institución real de la ciudad; a través del canal de esta institución se rectificó la conciencia religiosa del pecado" (Ricoeur, 2011. p. 265). Y es que en nuestra dimensión religiosa, nos hallamos en la Naturaleza sagrada, en la que lo que es, es bueno y lo malo solo se confunde con la nada, el no-ser, el no-ser-con, por ejemplo. Digamos aquí entonces pecado para referirnos a esa culpabilidad ontológico-religiosa, flotante; y digamos delito, para, a diferencia, de ésta, hablar del incumplimiento de las leyes sociales o de los principios individuales. Una cosa es la religiosidad y otra cosa es la ética, aunque ésta halle su base o razón de ser en aquella. Si desfundamos la ética y le damos valor absoluto, renunciando a nuestra dimensión religiosa, no puede haber, tan siquiera, un verdadero proyecto político, teológico-político, pues definitivamente, nos habríamos desarraigado y atomizado: "Esa pulverización de la culpa en múltiples culpabilidades subjetivas vuelve a poner en cuestión en $<<$ nosotros >> de la confesión de los pecados y pone de manifiesto la soledad de la conciencia culpable" (p. 263). 
es necesario, porque el hombre entra en modo histórico al romper con la pura inocencia ontológica, para reparar el olvido del Ser: "la Biblia no habla nunca del pecado más que desde la perspectiva de la salvación que libra de él. Esta <<pedagogía>> del género humano hace que abunde el pesimismo de la caída con el fin de que sobreabunde el optimismo de la salvación" (p. 415).

Buscar significado a nuestro nacimiento es como buscar el sentido de la vida y ya convinimos, si es que algo he logrado, que solo adelantaríamos algo invirtiendo la pregunta y empezando por buscar el sentido de la muerte. Aunque confusamente, lo hallamos en el amor sacrificial. Al invertir la pregunta no solo cambiamos el objeto de la vida por el objeto de la muerte sino que la inversión es total y cambiaremos la pregunta por una respuesta, pues la muerte, comentábamos, toma sentido al volverse contestataria, constituyéndose, así, como una respuesta. Para ser una respuesta, la muerte tiene el cometido de significar. De ahí que la voluntad de significar que acompaña al proyecto de nuestra muerte, se torne transgresión de nuestra finitud: "Lejos, pues, de advertir el estrechamiento de mi perspectiva afectiva estoy ante todo volcado en lo que hago; y lo que hago se intercala en la meta de lo que queda por hacer. Por consiguiente, en mi ingenuidad prerreflexiva, mi atención se dirige ante todo hacia la obra proyectada, hacia el prágma" (p. 69). Querer significar para la muerte es, de nuevo, cumplir con una función hermenéutica, pues "lo hermenéutico no quiere decir primeramente interpretar sino que, antes aún, significa el traer mensaje y noticia" (Heidegger, 2002. p. 91).

En este contexto, nos vamos despegando del temor a la muerte física para ocuparnos del temor a la muerte espiritual, tratando de evitarla y así el pecado a impedir ya no será el de la arbitrariedad del dolor sino el de la falta de conexión: "Esta vinculación entre la mancilla y el sufrimiento vivida en un estado de <<temor y temblor >>, ha sido tanto más tenaz que, durante mucho tiempo, proporcionó un esquema de racionalización, un primer esbozo de causalidad: si sufres, si estás enfermo, si fracasas, si mueres, es porque has pecado; el valor del sufrimiento como síntoma y detector de la mancilla se convierte en valor explicativo, etiológico del mal moral (...) Por eso ha sido preciso nada menos que el cuestionamiento de esa primera racionalización y la crisis de la que el Job babilónico y el Job hebreo fueron los admirables testigos, para disociar el mundo ético del pecado y el mundo físico del sufrimiento. Esa disociación ha sido una de las grandes fuentes de angustia de la conciencia humana; pues fue necesario que el sufrimiento se tornase absurdo $y$ escandaloso, para que el pecado, por su lado, accediese a su sentimiento propiamente espiritual; a ese terrible precio el temor inherente a éste pudo convertirse en temor a no amar suficientemente y disociarse del temor a sufrir, a fracasar, en suma, el temor a la muerte espiritual pudo escindirse del temor a la muerte física" (Ricoeur, 2011. p. 195).

\section{La dicha: más allá del principio del placer.}

La diferencia entre el placer y la felicidad ha sido un tema clásico y recurrente 
en la historia de la filosofía. Se trata de una problemática central pues de ella depende la orientación y el sentido, así como todas las decisiones en torno a cómo y en qué y con qué ligar nuestra energía. Desde los antiguos griegos se sospecha que el mero placer, sin falta de ser condenable, no es la clave para mantener el aliento vital sino, en todo caso, de modo secundario o auxiliar. Fundamentalmente, ocurre, si no he sido fagocitada por un nihilismo exterminador, que en algún momento (o en varios), me doy cuenta de que el placer es algo que me pasa y no algo que hago y, siendo que una muerte con sentido y una vida propia y plena que la procure, pasan más por un disponer que por un padecer, me veo invitada a plantearme un más allá del principio del placer e incluso a hacer valer el derecho a existir de mi conciencia y a poder dignificarla, pues aun cuando el inconsciente es divino y me impulsa en la urgencia de la vida, cubriendo las lagunas de mi apercibimiento, dando motivos cuando no hay tiempo para razones o cuando hay que reinventar las razones, solo una conciencia, que es inaugural e irrenunciable para la condición humana, por muy defectuosa que sea, y por muchas trampas en las que me enrede, puede dar cuenta de ese mismo inconsciente y de cómo nos relacionamos con él y en él.

Ciertamente, hay una búsqueda aparentemente activa del placer pero la búsqueda del placer suele ser, sobre todo si se alza soberana, un búsqueda desesperada y no una exploración esperanzada. Ya que debemos afrontar la muerte, opto por quererla significativa, y resulta que el placer por el placer solo nos puede matar de sobredosis o de un letal síndrome de abstinencia. Por supuesto, la lógica del vicio y las aventuras y desventuras del incontinente y del lascivo son dignas de estudio y, tras la conformación de dicho hábito, se hallan cientos de incógnitas sobre la exaltación, la euforia y la desdicha, así como de notas acerca del mismísimo funcionamiento orgánico. Pero la vida recreativa es puro divertimento, es decir, pura distracción. El placer nos entretiene, tal vez, de aquello que deberíamos atender.

Decía Pascal, como vimos, que la razón de todas nuestras desdichas es muy simple, es una desgracia natural: nuestra condición miserable, esa que consiste en ser frágiles y mortales. Somos desdichados porque, a pesar de nuestra miseria, el hombre quiere conocerse a sí mismo. De ahí que la diversión le parezca a Pascal una cierta "aversión por la verdad..." que podría hacernos más miserables aún, pues al conjunto de nuestros defectos se añadiría la falta de conocimiento, el disimulo, el autoengaño. Pensemos entonces, ¿qué hacemos solo por diversión o cuándo justificamos nuestros actos a través de la búsqueda de diversión? ¿A dónde nos lleva actuar solo por diversión? ¿No será la resaca de la diversión precisamente la desdicha de encontrarse ante la terrible idea de haber estado disimulando nuestra desgracia, nuestra debilidad, nuestra mortalidad y nuestra miseria?

Resulta siempre oportuno, para comprender qué sea algo o qué opera ese algo en nosotros o hacia dónde nos lleva, acudir a la génesis de la palabra que nombra ese algo, pues las palabras no son casuales ni fugaces sino que como las antiguas rocas, sedimentan, conservan, estabilizan el iris de sensaciones, intenciones y rumbos destinados por ese primer nombrar. Puesto que no 
hablamos como pensamos sino que pensamos como hablamos y puesto que el lenguaje está más allá de nuestra propia vida y más acá de nuestro propio alcance, sacar las palabras de nuestras expresiones, aislarlas e investigarlas, nos permite, mejor que ninguna otra cosa, comenzar con atino un análisis del drama de nuestra existencia, un viaje por nuestros deseos escondidos.

La palabra "diversión" proviene del latín diversum, superlativo de la acción nombrada por el verbo divertere que significaba alejar. De hecho la base del término, vers, quiere decir voltear, volver la espalda. Así, entendamos, que cuando decimos que queremos divertirnos estamos diciendo que queremos alejarnos. A menudo creemos que la diversión une, aproxima entretejiendo un lazo afectivo. Sin embargo, la diversión es un alejamiento, un quitarse algo de encima y lanzarlo hasta donde ya no podamos verlo. Así, no resulta la diversión algo que podamos definir positivamente sino que la diversión es un tipo de negación. De ahí que comprendamos mejor a Pascal en su sospecha ante lo divertido, pues tal vez nos disponga únicamente a evadir algo, que cómodo o incómodo, nos es esencial. Puede que en lo divertido solo nos estemos perdiendo. Puede que esta enajenación que es la diversión, aparezca, en nuestra experiencia, interrumpida, casi siempre, por accesos de culpabilidad. Demasiadas veces creímos acríticamente, ser críticos con esa autocondena de la diversión, que se nos antojó externa o, mejor dicho, internalizada a partir de operadores externos (nuestros padres, nuestros tutores, nuestros profesores, nuestros curas, nuestras instituciones morales...) que se empeñaron en alojar un policía extraño en nuestro interior. Demasiadas veces le echamos la culpa al cristianismo, al pensamiento judeo-cristiano que nos hizo de cuna. En cambio, reflexionemos hoy y advirtamos que el sentimiento de culpa y la mala conciencia que nos asalta cuando nos divertimos, esa sensación de caos, de decadencia, de que algo desagradable va a seguirnos después, no es la voz de Cristo sino la de un dios mucho más antiguo, la del que reúne todo lo diverso en lugar de dispersarlo hasta la nada. Eso divino que nos conmina al pensar, al saber, a la verdad, nos advierte de que lo que hacemos por diversión, nos separa de la autenticidad de nuestras obras.

Por si alguien se sintiera tentado de convocar al devenir del lenguaje y de cuestionar mi planteamiento, atestiguando el deslizamiento semántico de las palabras, debo repasar la conservación del significado original en nuestra propia expresividad popular, en esa que nos atraviesa cuando algo nos turba o nos conmueve. Decimos a los malos amantes: "Solo me quieres para divertirte", y, con ello, ni los alagamos ni nos sentimos alagados. Queremos acusarlos de no estar con nosotros estando con nosotros sino simplemente no estando con otra cosa y, en el límite, no estando ni siquiera con nosotros, con lo que nos es esencial, pues dando la espalda a la realidad, ese amante nos está alejando a nosotros de él, de la realidad y de nosotros mismos ¿Qué clase de estupidez es el sexo por diversión o el baile por diversión o incluso el juego por diversión? Es un no-sexo, pues no une ni llena sino que fractura y vacía hasta el sinsentido de la depresión postcoital. Es un no-baile, pues no nos permite desgarrarnos para celebrar nupcias con nuestro suelo, con nuestro compañero y con nuestro cielo. Es no-juego porque el verdadero jugador pone el alma en cada partida y envida su destino, saboreando el borde entre la vida 
y la muerte, la ganancia y la pérdida...

Diversión también significa distracción, en el lenguaje militar: se divierte al enemigo ¿Debemos, entonces, creer en la diversión? ¿Nos divierten los amigos o los enemigos? ¿De qué nos quieren distraer los que nos divierten y para qué sino para matarnos antes de que los matemos?

En Más allá del principio del placer, Freud se pregunta por el placer y la repetición, mostrando la anterioridad de ésta respecto de aquel. A través de la observación de los juegos infantiles y de la especificidad de los sueños traumáticos, nos ofrece el lado más tanático de ese preámbulo del placer que es la repetición. Lo que tiene de negativo el placer, es decir, lo que le da su carácter de reverso, de compensación, más que de propuesta o don, es su génesis funcional. Cuando descubrimos que no repetimos porque nos place sino que nos place porque repetimos, abandonamos la pregunta por el placer y nos adentramos en esa otra más enigmática: la pregunta por la repetición ¿Por qué repito?, ¿no es cierto que, cuando hago balance de mis repeticiones, encuentro en ellas más ruina que riqueza?, es decir, ¿no pasa que más bien me lamento por "haber caído en los mismo" que celebro el "otra vez"?, pero ¿no es patente también que antes de la crónica de ese lamento anunciado, me abandoné a la gustosa sensación de familiaridad perdida, al "por fin vuelvo a sentir lo mismo", aun cuando es lo mismo que no necesariamente acaba demasiado bien? ¿no me encuentro atrapada en eso que he definido como mis placeres, esperando que les suceda una dicha que nunca llega?, ¿por qué es placentero justo eso que me defrauda una y otra vez y que solo me deja con una sed de lo mismo que no me permite salir del bucle de decepción, de caida, de sinsentido (de pecado)? Parece que así es porque con el placer no realizo una auténtica búsqueda sino que escapo de algo, paradójicamente, por anticipación.

Lo que Freud viene a descubrir es que en la compulsión, no repito algo que me agrada sino algo que temo que, angustioso para mí, ocurrirá igualmente. Lo angustioso solo es placentero en contraste con lo que asusta, con lo que dolorosamente sobresalta. Con la repetición anterior convertimos en esperado y controlado lo que, si no, sería, además de desagradable, imprevisto. Repitiendo solo queremos estar preparados. Generamos angustia para evitar el pánico. Así, entiendo porqué en el placer siempre asoma un fondo masoquista: la auto-lesión hace de la lesión algo más indoloro. En un rulo algo complicado, preferimos ser artífices de nuestra propia desgracia que padecerla como imbéciles ingenuos. De modo tal, aparece la parodia: "no me abandonas; te echo", "no me echas; me voy". Con razón dice Marx que la historia se repite pero una vez como tragedia y otra como comedia. La comedia, la parodia, la farsa... las tenemos, ya en nuestro imaginario como más pobres y leves, pero, por eso mismo, como más llevaderas que la tragedia. Se trata de una condena mediante la risa (Bergson, 2008) o de tragarnos la desgracia con la lubrificación del juego.

Con el placer, el dolor sabe a desahogo. Sin embargo, cuando finalmente la 
desgracia llega de fuera, por mucho que la hallamos anticipado, es decir, por mucho que nos hallamos esforzado en conseguir una anestésica habituación, nos ahoga. Por ello, cuando van asociados al placer, no queremos que se cumplan nuestros deseos. El objeto del placer acaba volviéndose insípido cuando lo solicitamos o, cayendo sobre nosotros, sin el consentimiento de nuestra voluntad, aparece como cruz y condena. Los placeres son, como ya popularmente sabemos, pequeñas muertes, y, por mucho que queramos eludir la muerte adelantándonos a ella, "la muerte siempre viene de fuera" ${ }^{16}$. Lo único que podemos hacer es tratar de que esta desposesión, este inevitable dar, signifique, conforme una respuesta, un haber apostado por una conciencia que diga algo, que ofrezca, al menos un motivo de reflexión.

Frente a la desesperada persecución del placer, frente al siempre falaz intento de retener y agotarse en lo que, de suyo, ha de ser fugaz, puntual e insuficiente, la filosofía, como también la religión, instaron a maquinar un distinto modo de existencia, en el que el lugar del placer no fuera sino residual; un modo de existencia volcado hacia lo que tiene el poder de esenciar, de permanecer y de valer la pena. Pienso que salvar el alma sigue valiendo la pena. Así, recortar la vida en función de la proximidad con el placer y la lejanía con el dolor, puede, a lo sumo, servir, para conservarse, dada una acepción moderada, o para perderse, si nos colocamos en el trazado del exceso. Lo primero es mera supervivencia y no es vivir conforme a las potencias de lo humano, dicho éticamente. Lo segundo nos señala un lugar común, una irrefrenable huida hacia adelante, hacia el irrecuperable instante cero, hacia las fondos... No sé si esta experiencia es necesaria para un reflote más brillante que la lineal retención o, si, por el contrario, una puede ocuparse de sí solo a pesar de tal hundimiento, más que inspirada por él. En cualquier caso, sabemos ya que estar perdida constituye la situación natural de quién transita el medio de las cosas, el medio de un bosque, de un océano, de un desierto, de cualquier meseta extendida entre el nacimiento y la muerte, entre la pregunta y la respuesta o entre el absurdo y la significación. Pero el encontrarse perdida no constituye la culminación de ningún viaje sino que siempre hay un norte hacia el que enderezar el rumbo. Hay un camino de virtud que algunos llamaron felicidad y otros ascesis y otros beatitud, en el que buscar alojamiento para cumplir con la propia esencia.

Esta vez vamos a quedarnos con el nombre que Paul Ricoeur le da a este más allá del placer en el que encontramos esencia y transcendencia o, lo que es lo mismo, sentido, esa transgresión de la finitud mediante el deseo de significar: la dicha. Quedarnos con el nombre no es una cuestión superficial sino un motivo para especificar, para darle a Ricoeur la particularidad y distinción de su propuesta. Puede que tanto si traemos la eudaimonía de Aristóteles como la beatitud de Spinoza, la dicha de Ricoeur e incluso el temor y el temblor de Kierkegaard, estemos tratando con el amor intelectual a Dios. En cambio, quiero conceder a cada uno su originalidad e inclinación a la hora de tratarlo, pues son diferentes los acentos que ponen y las fascinaciones que producen.

16 G. Deleuze: "Spinoza”. Le cours de Gilles Deleuze.

http://www.webdeleuze.com/php/texte.php?cle=44\&groupe=Spinoza\&langue=3. 
Con razón, se traduce el término bonheur del francés de Ricoeur como dicha. Efectivamente es un nombre que le damos a la felicidad siempre y cuando queremos diferenciarla no solo del placer sino también de alegrías que bien pueden ser pasajeras; y siempre que queremos mentar un edificar en lugar de un padecer. El vocablo francés procede del latín "augurium", algo así como aumento que los dioses insuflan a un emprendimiento. La palabra latina deriva del indoeuropeo "aweg" entendido también como augurio en sentido de reconstitución, concesión de autoría, de derecho de autor. Así, bonheur pone en relación la propia existencia, el propio proyecto, con el aval divino. Se trata de una potenciación, de una capacitación que los dioses me dan para reconstituirme en el obrar. Se me pone en la existencia pero, en mi empresa, me reconstituyo con el augurio divino. En esta reconstitución tomo derechos de autor.

Lo que es importante destacar es el modo complejo y clásico en el que se nos permite entender el augurio divino. En él confluyen destino divino y obra propia. El augurio hace referencia a un vaticinio, a un desciframiento. Puedo comprender con legitimidad que la felicidad enraizada en el buen augurio consiste, en la buena interpretación de los signos, en un caminar descifrando las señales divinas. Se conceden derechos de autor para reconstituir y entiendo para reconstituir el destino y traer el mensaje. La felicidad es un hacer pero, sobre todo, es un saber decir lo que simbolizan los dioses.

En castellano, se adjudica a esta felicidad particularmente ricoeuriana, el nombre de Dicha. De este modo conservaríamos la mayor proximidad, aun en la torsión del texto traducido. La palabra dicha viene del latín "dicta", las cosas dichas. Si atendemos a la significación más original del verbo "dicere" del que proviene este nominativo neutro relacionado con la raíz indoeuropea "deik", lo traducimos como indicar, señalar. Dicta se refería a las cosas indicadas por el destino de una persona al nacer. Fatum y dicta harían referencia al destino pero en el primer caso evolucionaría como destino fatídico y en el segundo como destino favorable. En cualquiera de los dos hilos nos encontramos con la fatalidad y solo por una especie de afección mediante, parece que sentimos esa fatalidad adversamente, como si resultara muy costoso u obstaculizado su camino; o favorablemente, con "el viento a favor", como impulsados en la dirección que corresponde. Observamos que la dicha corresponde a una felicidad que implica un decir en el que somos destinados al nacer y y un decir con el que desciframos recorriendo el destino con el viento a favor, excitados, impelidos, atraídos con él hacia él.

La dicha, el buen augurio, son la felicidad que construimos en los límites del destino. La felicidad consistiría, entonces en interpretarse dentro de la interpretación que hacemos de los símbolos de la naturaleza o de un texto sagrado. Más allá del placer, lo que da adecuada orientación a la vida es la dedicación a la interpretación de los signos, para poder dar significado y para poder decir (traer mensaje y noticia), al final, con la muerte: dar significado para significar. 
De este modo me gustaría reformular el círculo hermenéutico. Este círculo da cuenta de la desproporción mencionada con anterioridad, entre la finitud de la perspectiva y la infinitud en la que se aloja el sentido. Por ello la hermenéutica de Ricoeur es ascética. Nuestro nacimiento es el acontecimiento de otro que nos da un carácter y, de camino a la muerte, para que aquel se "disuelva", se transgreda, en el sentido, buscamos las señales para poder decir lo que nos dicen. Esta comprensión requiere una anticipación de la fe, una puesta en marcha esperanzada: "La <<desproporción>> entre el sentido y la perspectiva, entre el querer-decir y el mirar, entre el verbo y el punto de vista es como la célula melódica de todas las variaciones y de todos los desarrollos que culminan en la <<desproporción>> entre la dicha y el carácter" (Ricoeur, 2011. p. 82); "Yo, que soy perspectiva finita, dilección por mi cuerpo, hábito e inercia, carácter soy capaz de concebir la idea del <<querer perfecto de un ser racional dotado al mismo tiempo de omnipotencia>>; o, por retomar otra expresión kantiana evocada más arriba, yo soy portador del $<<$ destino supremo de la razón >>, conforme a la cual puedo <<continuar mi existencia >>. Esta idea del querer perfecto y del destino de la razón abren en mi deseo una profundidad infinita y lo convierten en el deseo de la dicha y no sólo en el deseo del placer" (p. 85); "Lo mismo que recojo indicios del estrechamiento de mi percepción aunque sólo sea por la refutación de los demás-, recojo signos de estar destinado a la dicha. Se trata de experiencias privilegiadas, de momentos especiales en los que recibo la seguridad de ir en la dirección acertada; de pronto, el horizonte se despeja, ante mí se abren posibilidades ilimitadas; el sentimiento de lo <<inmenso>> responde entonces dialécticamente al sentimiento de lo <<estrecho>>" (p. 86); "El carácter es el origen cero de esta orientación de campo, la dicha es el término infinito de la orientación. Esta imagen hace comprender que la dicha no se da en ninguna experiencia; únicamente es designada en una conciencia de dirección. Ningún acto proporciona la dicha; pero los encuentros de nuestra vida más dignos de ser llamados <<acontecimientos>> indican la dirección de la dicha (...) Los acontecimientos que hablan de la dicha son aquellos que apartan los obstáculos, que descubren un amplio paisaje de existencia; el exceso de sentido, el excedente, lo inmenso, ésta es la señal de que estamos <<dirigidoshacia $>>$ la dicha" (p. 86); "<<Hay que comprender para creer, pero hay que creer para comprender. Este círculo no es un círculo vicioso,menos aún mortal; es un círculo lleno de vida y estimulante. Hay que creer para comprender: en efecto, el intérprete no se aproximará jamás a lo que dice su texto si no vive en el aura del sentido en cuestión..." (p. 485).

\section{Hermenéutica y amor: obrar en el encuentro.}

Como conclusión, solo quiero ofrecer un muy breve resumen de mi exposición que ayude a asentar una lógica de saltos temáticos o un panorama de asociaciones conceptuales, mostrando, a su vez, cómo mi escrito reivindica la observación atenta de la fe, la salvación y la dicha, tanto para alimentar el brío vital y dar un sentido a la muerte como para comprender adecuadamente la afectividad humana.

A veces anhelamos la inocencia de la animalidad salvaje y desearíamos ser 
despreocupadamente inconscientes. A veces, dándonos cuenta de que dicha vuelta es imposible, quisiéramos acogernos a una total superestructuración, para, del mismo modo, no tener que responder de nuestros actos y descansar en códigos arbitrarios, que se nos antojaran puramente estéticos en el olvido de su génesis. Por caminos contrarios, buscamos, así, descansar de la reflexión que nos agota y dejar que nuestro cuerpo funcione solo, conducido por una eficacia desconocida que nos permita escapar de la interrogación. Pero no por mucho tiempo logramos mantenernos en este equilibrio insospechado, pues de pronto, nos hallamos en situaciones inéditas que nos interpelan exigiendo decisiones, elecciones y tomas de partido. Entonces, solo un consciente y miserable abandono en la decadencia voluntaria, nos permitiría continuar, indolentes y crueles, en una existencia caótica sin proyectos ni interrogantes. Amar sin preguntar no es amar o no es amar humanamente, pues quien no quiere saber nada es que sobrevive sin interés alguno ya por la vida: "Si no se acepta la desproporción originaria del deseo vital y del amor intelectual (o de la dicha espiritual), se pierde totalmente la especificidad de la afectividad humana" (Ricoeur, 2011. p. 110) Respetar el misterio, dejarlo ser, es interrogarlo aun sin pretender despejarlo o despojarlo de su esencia, pues el misterio gusta de ocultarse pero también de dar señales.

No es por abundancia que prescindamos del sentido, ni de auténtica vitalidad que nos sobre. Eludir la pregunta por el sentido de la vida solo muestra la cobardía de haberse acomodado en el fracaso anticipado. Exterminar sin más tal cuestionamiento equivale a renunciar torpemente de nuestra humana condición para mecerse en el frenesí de los placeres. Incluso si optamos por un nihilismo tal, más pronto que tarde, advertiremos que las resacas son cada vez más insoportables y nos veremos obligados a reorientarnos o a morir insignificantemente, a morir, tristemente, del todo, para todo y para todos. Por muy perdidos que nos encontremos, no queremos tal cosa. De hecho, la sensación de estar perdidos indica ya una búsqueda irrenunciable. En los paraísos artificiales también ansiamos la eternidad y eso no podemos negarlo.

Ya un pronto filosófico, ya un arrebato religioso, ya un ardor artístico, nos inclina a crear un sentido para la vida pero, en lo profundo, intuimos que ni creamos de la nada ni nos contentamos con meros divertimentos sino que creamos para reconstruir aquello que nos empuja y llama: el destino. Nos queremos destinados-a, pues a falta de tal sentimiento de destinación, no encontramos más motivo que nuestra propia mismidad y ese es un nombre de la soledad y la desconexión.

Tal vez la primera de las situaciones inéditas y grandiosas a las que me refería hace un momento, esas que nos exigen una elección, un procesamiento, sea el encuentro con la muerte, pues es mi convencimiento que solo en el abismo incomprensible de la muerte, nuestra niña comienza a filosofar. Por ello propongo que la persecución del sentido de la vida es solo un modo amable y segundo de nuestra necesidad de explicarnos y reconciliarnos con la muerte.

El primer encuentro terrible con la muerte no nos impactaría si no fuera por el 
amor que guardamos, porque ya en ese momento amamos. Puede que gracias a esa trágica experiencia sepamos verdaderamente del alcance de nuestro amor, de un amor que no se adecua sin más a la ausencia. No podemos decir, como avisa Heidegger, que la ausencia no es pues tanto es que duele. Aprender a vivir con aliento es aprender a vivir con ese dolor de la finitud que nos impele a transgredirla. Aprender a vivir con aliento es vivir más allá de la vida, hacia un más allá de esto actual que se fuga constantemente. Es por eso que no nos sirven los placeres sino que aspiramos a la dicha. $Y$ es por eso que no nos conformamos con amoríos menores sino que más allá de ellos o incluso en ellos, buscamos una conexión que nos permite ser algo más que nosotros mismos, que nos permita no terminar en los límites de nuestra superficie: "el placer acentúa y afianza mi arraigo orgánico en el mundo; magnifica el cariño que le tengo a la vida que me atraviesa y ese centro de perspectiva que soy; así pues, la perfección misma del placer es la que me ata a la vida, pues manifiesta que vivir no es una actitud más entre otras, sino la condición existencial de todas las demás; al afirmar alegremente aquello de <<primero vivir>>, el placer no deja de sugerir constantemente el aplazamiento de $<$ <después filosofar >>. Y, no obstante, el placer es total, como la dicha; representa la dicha en el momento; pero precisamente esa contracción de la dicha en el momento es lo que amenaza con paralizar el dinamismo del obrar en la celebración del Vivir" (p. 112). Por suerte, nuestros cuerpos están animados, almados, y no terminan en su recortada figura ni en su limitada perspectiva sino que se expanden todo lo que se expande su potencia. Es ahí que la fantasía de conexión nos permite sentir el éxtasis y, así, repartiéndonos, prolongarnos en los otros, en lo otro.

Sin embargo, dado que igual que topamos con la experiencia de la muerte, topamos con la experiencia y la angustia del desamor, solo la fe nos salva de un nuevo ensimismamiento. La fe es la confianza que persiste a las sucesivas confianzas quebradas. La fe es el más allá del duelo y la melancolía. Solo en ella realizamos la apertura a nuevos encuentros, bien puedan darse en la sociabilidad o en el retiro.

Me gustaría, para terminar, rememorar la importancia de los ciclos y valorizar, también como acto de amor, el retiro, incluido el retiro definitivo de la muerte, si con él conseguimos responder, si logramos un retiro y una muerte contestatarios que signifiquen, aporten mensaje y noticia, en el regreso al hogar, tras la aventura del desciframiento. Hacer el amor es hacer hermenéutica, ya sea ésta inconclusa. El acto de amor acabado es aquel por el que, esperanzados, afrontamos la muerte, a condición de significar algo con ella, de redondear el obrar cumplido. Obramos en el encuentro pero, en el retiro, conseguimos encontrarnos con las voces que no se oyen entre el griterío y el alboroto, con las voces de los muertos que nos dejaron algo que leer, con las voces que forman ya parte de lo divino. Quizás incluso, con el retiro definitivo, propiciemos un momento de silencio entre el griterío y el alboroto, un momento para la reflexión. 


\section{Bibliografía}

Bataille, Georges. El erotismo. Barcelona: Tusquets. 2007. Bergson, Henri. La risa. Madrid: Alianza. 2008.

Deleuze, Gilles: Lógica del sentido. Barcelona: Paidós. 1989.

Freud, Sigmund. Obras completas. Barcelona: RBA. 2006.

Hume, David: Investigación sobre el entendimiento humano. Madrid: Istmo. 2004.

Kierkegaard, Soren. Temor y temblor. Madrid: Tecnos. 1987.

Kierkegaard, Soren. Las obras del amor. Salamanca: Sígueme. 2006.

Kirk, G. S., Raven, J. E., Schofield, M. (1994) Los filósofos presocráticos.

Madrid: Gredos.

Klein, Melanie. Obras completas. Barcelona: RBA. 2006.

Pascal, Blaise. Pensamientos. Madrid: Alianza. 2004.

Ricoeur, Paul. Hermenéutica y acción. Buenos Aires: Prometeo Libros. 1988.

Ricoeur, Paul. Fe y filosofía. Buenos Aires: Prometeo Libros.2008.

Ricoeur, Paul. Finitud y culpabilidad. Madrid: Trotta. 2011.

Ricoeur, Paul. Amor y justicia. Madrid: Trotta. 2011 (b). 